United States Department of Energy

Savannah River Site

\title{
Electromagnetic Borehole Flowmeter Testing at the H-Area Extraction Wells (U)
}

WSRC-TR-2002-00187

Revision 0

May 2002

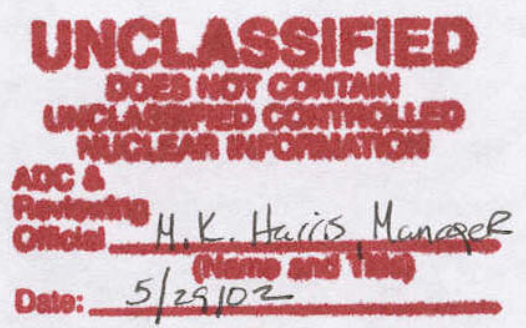

Prepared by:

Westinghouse Savannah River Company LLC Savannah River Site

Aiken, SC 29808

Prepared for the U.S. Department of Energy Under Contract No. DE-AC09-96SR18500 
This document was prepared in conjunction with work accomplished under Contract No. DE-AC09-96SR18500 with the U. S. Department of Energy.

\section{DISCLAIMER}

This report was prepared as an account of work sponsored by an agency of the United States Government. Neither the United States Government nor any agency thereof, nor any of their employees, makes any warranty, express or implied, or assumes any legal liability or responsibility for the accuracy, completeness, or usefulness of any information, apparatus, product or process disclosed, or represents that its use would not infringe privately owned rights. Reference herein to any specific commercial product, process or service by trade name, trademark, manufacturer, or otherwise does not necessarily constitute or imply its endorsement, recommendation, or favoring by the United States Government or any agency thereof. The views and opinions of authors expressed herein do not necessarily state or reflect those of the United States Government or any agency thereof.

This report has been reproduced directly from the best available copy.

Available for sale to the public, in paper, from: U.S. Department of Commerce, National Technical Information Service, 5285 Port Royal Road, Springfield, VA 22161, phone: (800) 553-6847, fax: (703) 605-6900

email: orders@ntis.fedworld.gov

online ordering: http://www.ntis.gov/help/index.asp

Available electronically at http://www.osti.gov/bridge

Available for a processing fee to U.S. Department of Energy and its contractors, in paper, from: U.S. Department of Energy, Office of Scientific and Technical Information, P.O. Box 62, Oak Ridge, TN 37831-0062,

phone: (865)576-8401,

fax: (865)576-5728

email: $\underline{\text { reports@ adonis.osti.gov }}$ 
Electromagnetic Borehole Flowmeter Testing

WSRC-TR-2002-00187

at the H-Area Extraction Wells (U)

Revision 0

Savannah River Site

May 2002

Approvals:
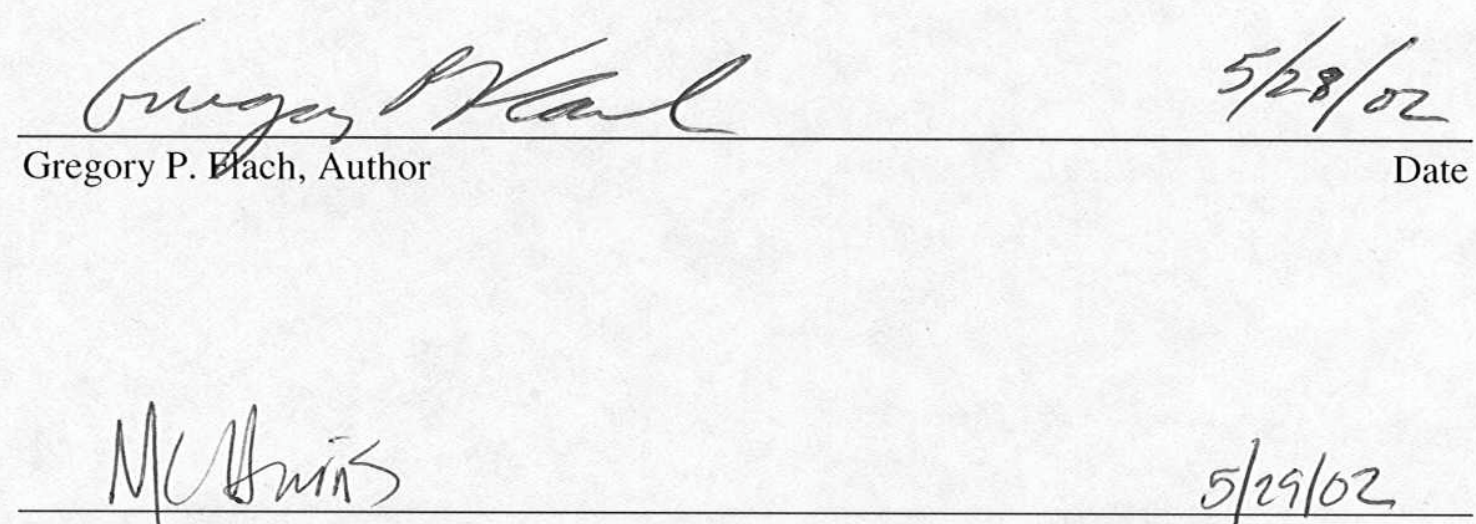

Mary K. Harris, L4 Manager

Date

P. Casey ofmaph. $6 / 03 / 02$ 


\section{TABLE OF CONTENTS}

SECTION:

Page No.

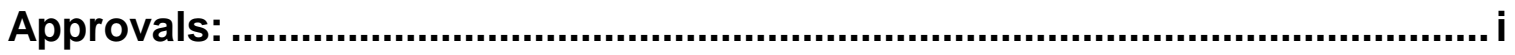

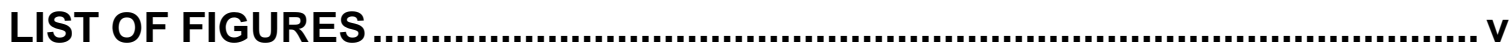

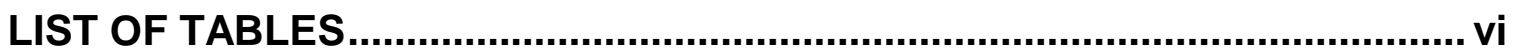

LIST OF ACRONYMS AND ABBREVIATIONS ........................................... vii

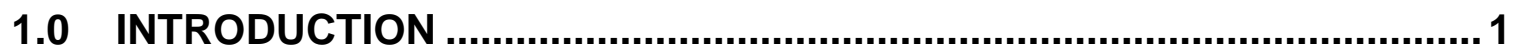

1.1 Test Design.......................................................................................................... 1

1.2 Test Equipment ............................................................................................................... 4

1.3 Test Procedures ...........................................................................................................5 5

1.4 HEX-3 Data Analysis.............................................................................................6 6

1.5 HEX-4 Data Analysis..................................................................................9

1.6 HEX-18 Data Analysis ................................................................................ 10

2.0 DISCUSSION ................................................................................. 11

3.0 RECOMMENDATIONS ................................................................. 12

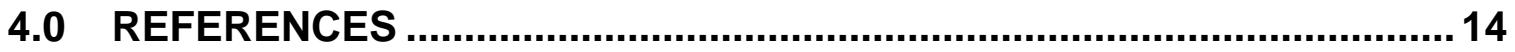

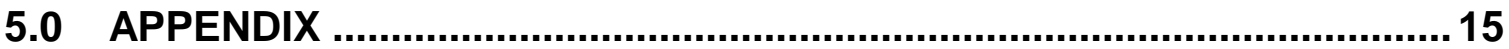




\section{LIST OF FIGURES}

FIGURE 1. LOCATIONS OF HEX WELLS.............................................................16

Figure 2. SCHEMATIC Diagram OF THE ELECTROMAGNETIC BOREHOLE

FLOWMETER; REPRODUCED FROM MOLZ AND YOUNG (1993) ................ 17

Figure 3. ELECTROMAGNETIC BOREHOLE FLOWMETER (EBF) APPLICATION OF FARADAY'S LAW OF INDUCTION; REPRODUCED FROM MOLZ AND YOUNG (1993)

FiguRE 4. SCHEMATIC ILLUSTRATION OF BOREHOLE FLOWMETER TESTING; REPRODUCED FROM MOLZ AND YOUNG (1993) ......................................... 19

Figure 5. BASIC GEOMETRY AND ANALYSIS OF BOREHOLE FlOWMETER DATA; REPRODUCED FROM MOLZ AND YOUNG (1993) ......................................... 20

Figure 6. CONFIGURATION OF PRIMARY TEST EQUIPMENT....................................... 21

Figure 7. WIRE-WRAP SCREEN CONSTRUCTION AND BYPASS FLOW PHENOMENON .......................................................................................22

FIGURE 8. RAW FLOW DATA FOR HEX-3 ................................................................ 23

Figure 9. Cumulative Flow Logs for HeX-3, Preliminary and INTERPRETED

Figure 10. Preliminary Estimates of Hydraulic Conductivity, Tritium CONCENTRation and MaSS FluX, REFERENCED to SCREEN AVERAGE VALUES FOR HEX-3

Figure 11. Revised Estimates OF HydraUlic CONDUCTIVITY, Tritium CONCENTRATION AND MASS FluX, REFERENCED TO SCREEN AVERAGE VALUES FOR HEX-3

FIGURE 12. CUMULATIVE FLOW LOG FOR HEX-4........................................................2 27

Figure 13. Estimates OF HYdRaUlic CONDUCTIVITY, TRITIUM CONCENTRATION AND MASS FluX, REFERENCED TO SCREEN AVERAGE VALUES FOR HEX-4 .28

Figure 14. Cumulative Flow Logs for HeX-18, Preliminary and INTERPRETED.

Figure 15. Preliminary Estimates of Hydraulic Conductivity, Tritium CONCENTRATION AND MASS FluX, REFERENCED TO SCREEN AVERAGE VALUES FOR HEX-18 30

FiguRE 16. REVISED ESTIMATES OF HydRAULIC CONDUCTIVITY, TRITIUM CONCENTRATION ANd MaSS FluX, REFERENCED to SCREEN AVERAGE VALUES FOR HEX-18 
Electromagnetic Borehole Flowmeter Testing

WSRC-TR-2002-00187

at the H-Area Extraction Wells (U)

Revision 0

Savannah River Site

May 2002

Page vi of vii

\section{LIST OF TABLES}

TABle 1. Well CONSTRUCTION INFORMATION FOR HEX WELl...................... 32

TABLE 2. PRELIMINARY DATA ANALYSIS FOR HEX-3 ...................................... 33

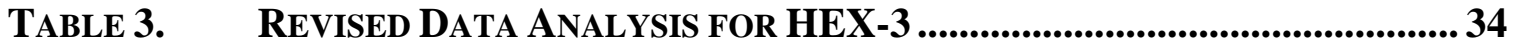

TABLE 4. DATA ANALYSIS FOR HEX-4 .................................................................... 35

TABLE 5. PRELIMINARY DATA ANALYSIS FOR HEX-18 ..................................... 36

TABLE 6. REVISED DATA ANALYSIS FOR HEX-18 ........................................... 37 
Electromagnetic Borehole Flowmeter Testing

WSRC-TR-2002-00187

at the H-Area Extraction Wells (U)

Revision 0

Savannah River Site

May 2002

Page vii of vii

\section{LIST OF ACRONYMS AND ABBREVIATIONS}

$\begin{array}{ll}\mathrm{cm} & \text { centimeter } \\ \mathrm{CPT} & \text { cone penetrometer testing } \\ \mathrm{EBF} & \text { electromagnetic borehole flowmeter } \\ \mathrm{GEL} & \text { General Engineering Laboratory } \\ \mathrm{L} / \mathrm{min} & \text { liter per minute } \\ \mathrm{mL} & \text { milliliter } \\ \mathrm{msl} & \text { mean sea level } \\ \mathrm{pCi} & \text { picocurie } \\ \text { TOC } & \text { top of casing }\end{array}$




\subsection{INTRODUCTION}

Electromagnetic Borehole Flowmeter (EBF) testing has been used at several locations at the Savannah River Site to characterize hydraulic conductivity variation along well screens (Phifer 1996, Boman et al. 1997, Flach et al. 2000a and b, Flach et al. 2001). The objective of the EBF testing documented in this report is to expand the technology to include simultaneous characterization of conductivity, contaminant concentration, and mass flux profiles. The latter two parameters, especially mass flux, can be valuable information for remedial design.

Mass flux refers to contaminant mass flow rate per unit length of well screen. The basic idea is to take samples of the groundwater passing through the EBF and have them analyzed in the laboratory for contaminant concentration. The product of EBF flow and laboratory concentration provides an estimate of the mass flux entering the portion of the well screen below the EBF. The cumulative flow and mass flux data can then be used to find conductivity, concentration and mass flux entering the well along each screen interval. This expanded capability has been demonstrated for tritium at three extraction wells associated with the $\mathrm{H}$-area seepage basin pump and treat-reinject remediation system, HEX-3, HEX-4 and HEX-18. Figure 1 shows the locations of these wells and Table 1 provides basic well construction information.

This study was initiated through Technical Assistance Request ERE-TAR-20010027 and conducted in accordance with a Task Technical and Quality Assurance Plan (Flach and Ekechukwu 2001).

\section{$1.1 \quad$ Test Design}

The use of an EBF to determine the vertical variation in horizontal hydraulic conductivity along a well screen has been documented (e.g., Waldrop 1995; Molz 
and Young 1993; Flach et al. 2000a). Past Savannah River Site applications include Phifer (1996), Boman et al. (1997), and Flach et al. (2000a, b). The EBF measures vertical flow inside a well casing based on Faraday's Law of Induction, which states that the voltage induced by a conductor moving at right angles through a magnetic field is directly proportional to the velocity of the moving conductor (Waldrop 1995). Schematic diagrams of the EBF are shown in Figures 2 and 3 (Molz and Young 1993). In this application, groundwater acts as the moving conductor, an electromagnet generates the magnetic field, and the electrodes measure the induced voltage.

The idea behind EBF testing is to relate horizontal conductivity as a function of elevation, $\mathrm{K}(\mathrm{z})$, to borehole discharge as a function of elevation $\mathrm{Q}(\mathrm{z})$. The field procedure is schematically illustrated in Figure 4. Under quasi-steady pumping conditions, borehole discharge (Q) from the bottom of the screen up to the current flowmeter position is measured as a function of elevation (z). As shown in Figure 5 , the difference $(\Delta \mathrm{Q})$ in borehole discharge $\mathrm{Q}(\mathrm{z})$ between any two locations is the flow rate of groundwater entering the well casing over that interval. This differential flow rate, minus any ambient flow effects, is directly proportional to the horizontal conductivity of the aquifer over that interval. The data analysis procedure is summarized by

$$
\frac{\mathrm{K}_{\mathrm{i}}}{\overline{\mathrm{K}}}=\frac{\left(\Delta \mathrm{Q}_{\mathrm{i}}-\Delta \mathrm{q}_{\mathrm{i}}\right) / \Delta \mathrm{z}_{\mathrm{i}}}{\sum_{\mathrm{i}}\left(\Delta \mathrm{Q}_{\mathrm{i}}-\Delta \mathrm{q}_{\mathrm{i}}\right) / \sum_{\mathrm{i}} \Delta \mathrm{z}_{\mathrm{i}}}
$$

where:

$$
\begin{aligned}
& \mathrm{K}_{\mathrm{i}} \equiv \text { horizontal conductivity of the } \mathrm{i}^{\mathrm{th}} \text { interval } \\
& \overline{\mathrm{K}} \equiv \text { vertically-averaged conductivity }
\end{aligned}
$$


$\Delta \mathrm{Q}_{\mathrm{i}} \equiv \quad$ difference in EBF flow at the top and bottom of the $\mathrm{i}^{\text {th }}$ interval under pumping conditions

$\Delta \mathrm{q}_{\mathrm{i}} \equiv$ difference in EBF flow at the top and bottom of the $\mathrm{i}^{\text {th }}$ interval under ambient conditions

$\Delta \mathrm{z}_{\mathrm{i}} \equiv$ height of the $\mathrm{i}^{\text {th }}$ interval.

In equation (1), $\left(\Delta \mathrm{Q}_{\mathrm{i}}-\Delta \mathrm{q}_{\mathrm{i}}\right)$ is the net flow rate induced by pumping and accounts for ambient flow effects. Ambient flow refers to horizontal flow through the well screen and vertical flow in the casing under natural, undisturbed conditions. Note that the relative conductivity distribution is equal to the relative distribution of net flow entering the well, which is assumed to occur after the initial transient passes and after quasi-steady state conditions develop.

To determine concentration and mass flux distributions, additional measurements are needed. By measuring the concentration of a contaminant in groundwater passing through the EBF at each elevation, the mass flux entering the wellbore over the $\mathrm{i}^{\text {th }}$ interval can be computed from

$$
\mathrm{m}_{\mathrm{i}}=\mathrm{Q}_{\mathrm{i}+1} \mathrm{C}_{\mathrm{i}+1}-\mathrm{Q}_{\mathrm{i}} \mathrm{C}_{\mathrm{i}}
$$

where

$$
\begin{aligned}
& \mathrm{m}_{\mathrm{i}}=\text { mass flux entering the wellbore over the } \mathrm{i}^{\text {th }} \text { interval } \\
& \mathrm{Q}_{\mathrm{i}}=\quad \begin{array}{l}
\text { cumulative flow entering the wellbore from the bottom of the } \\
\text { screen up to the } \mathrm{i}^{\text {th }} \text { elevation }
\end{array} \\
& \mathrm{C}_{\mathrm{i}}=\quad \text { concentration in the cumulative flow passing through the EBF } \\
& \text { at the } \mathrm{i}^{\text {th }} \text { elevation }
\end{aligned}
$$


The concentration in the formation at the $\mathrm{i}^{\text {th }}$ screen interval is computed from

$$
\mathrm{c}_{\mathrm{i}}=\frac{\mathrm{m}_{\mathrm{i}}}{\Delta \mathrm{Q}_{\mathrm{i}}}=\frac{\mathrm{Q}_{\mathrm{i}+1} \mathrm{C}_{\mathrm{i}+1}-\mathrm{Q}_{\mathrm{i}} \mathrm{C}_{\mathrm{i}}}{\mathrm{Q}_{\mathrm{i}+1}-\mathrm{Q}_{\mathrm{i}}}
$$

where

$$
\begin{aligned}
c_{i}= & \text { concentration in groundwater entering the wellbore over the } i^{\text {th }} \\
& \text { interval. }
\end{aligned}
$$

Equations (1) through (3) summarize the technical basis for the borehole flowmeter testing in groundwater monitoring wells planned for the HEX wells.

\subsection{Test Equipment}

A schematic diagram showing the configuration of the primary equipment used to perform the field test is shown in Figure 6. Borehole flow measurements were taken using a Century Geophysical Corporation system consisting of the downhole EBF instrument, a 300-meter drawworks, and a Compu-Log data acquisition computer. Well discharge was induced using a Grundfos Redi-Flo2 submersible pump mounted on a center discharge hose reel and driven by a variable speed controller. Groundwater samples were taken using a small bladder pump operated through an electronic controller supplied with compressed nitrogen, and attached to $85 \mathrm{ft}$ of 1/4" tubing on a reel. Both of the pumps were mounted on the EBF instrument and traveled together as a unit by operating the drawworks. A portable generator and uninterruptable power supply provided electrical power. 


\subsection{Test Procedures}

To rigorously account for potential ambient flow effects, the standard borehole flowmeter test procedure entails two series of measurements acquired through the following actions:

1) Under ambient conditions, measure the vertical flow rate inside the well screen at 1 - to 2 -ft intervals.

2) Pump (or inject) at a constant rate above the screen zone and borehole flowmeter.

3) Pause until the drawdown reaches a quasi-steady-state.

4) Under these quasi-steady-state pumping conditions, again measure the vertical flow rate inside the well screen at 1 - to 2 -ft intervals.

If ambient flows are small compared to dynamic flows, step 1 may be omitted. The quasi-steady-state conditions referred to in step 3 typically occur within 15 to 30 minutes in confined aquifers and within a couple of hours in unconfined aquifers.

For testing at the HEX wells, a 2-ft measurement interval was chosen. Ambient flows were expected to be small so ambient flowing testing was assumed to be unnecessary. The ambient test was performed at HEX-4 to check this assumption. Under dynamic (pumping) conditions, a 100-mL groundwater sample was acquired with each flow measurement. The GEL Mobile Laboratory performed tritium analyses on the groundwater samples. Instrument calibration and field procedures were documented by Flach and Ekechukwu (2001a) and in Controlled Notebook WSRC-NB-2001-00167. 


\subsection{HEX-3 Data Analysis}

EBF testing was performed on HEX-3 on February 4, 2002, between approximately 11:30 AM and 3:30 PM. The extraction system pump was shut off approximately 24 hours in advance of EBF testing. Preliminary field and laboratory data are presented in Table 2. The rubber skirt used to create a seal between the borehole flowmeter tube and well casing allowed personnel to locate the beginning and end of wire-wrap screen sections by feel. Specifically, the EBF assembly would often "hang up" at the start of each screen section as the rubber gasket encountered the longitudinal spacer ribs (Figure 7). Slack or tightening in the drawworks cable was observed in these cases. By monitoring cable tension, personnel determined that the $15-\mathrm{ft}$ screen interval comprised a $5-\mathrm{ft}$ section on top of a 10-ft section (Table 2). The top of the screen appeared to be approximately 1 $\mathrm{ft}$ deeper than indicated on the well construction diagram.

The rubber skirt provides a good seal along a smooth well casing, but only a partial seal along the wire-wrap screen because of the longitudinal spacer ribs (Figure 7). Consequently, the EBF generally measures a fraction of the flow that enters the screen and moves up the wellbore. However, at the joint between two screen sections where the inner wall is smooth, the rubber gasket apparently forces all flow through the EBF. This is indicated by the raw flow rate data from HEX-3 (shown in chronological order) in Figure 8. Flow measurements were taken at 2-ft intervals marching up the screen, and then back down the screen. Depth measurements were referenced to the top of the protective casing. After the measurement at a $28.5 \mathrm{ft}$ depth during the downward series of measurements, the EBF was moved back to $27.5 \mathrm{ft}$ where the joint between screen sections occurs. Here the flow reading was substantially higher than those of the surrounding two measurements. The high flow reading was confirmed after the downward run was completed, when the EBF was repositioned to $27.5 \mathrm{ft}$ to conclude testing. At the joint, the EBF-measured flow is roughly twice that immediately above and below. 
The precise fraction of total flow passing through the EBF is estimated to be 0.53 in Table 2.

At depths where two readings were taken, the best-estimate is taken as the average of the two measurements. The total flow entering the wellbore below a measurement interval can be estimated by dividing the best-estimate EBF reading by the bypass flow ratio, 0.53 , except at the joint between screen sections. Figure 9 shows the result of averaging and correcting for bypass flow. It also shows the flow rate of the Redi-Flo2 pump, corrected for head losses between the diversion valve where bucket-and-stopwatch measurements were taken and the radiological "buffalo" tank. The correction is based on post-test experimentation at 704-D that indicated the additional tubing past the diversion valve results in a $10 \%$ flow reduction (WSRC-NB-2001-00167). The Redi-Flo2 pumping rate corresponds to the total flow entering the wellbore.

The flow profile shown in Figure 9 is peculiar in that the cumulative flow rate decreases between an elevation of 9 and $11 \mathrm{ft}$ (depths of 28.5 and $26.5 \mathrm{ft}$ ). In principle, the cumulative flow log should be strictly non-decreasing. That is, flow should increase or, at worst, equal that of the next lower station (Figure 4). Technically this statement is only true of the net difference between dynamic and ambient flow rates (cf. eqn. (1)). Ambient testing was not performed at HEX-3; however, as expected, the ambient flows measured in nearby HEX-4 were negligible compared to the dynamic flows. Therefore, ambient flow does not explain the cumulative flow decreases. Instrument error is another possible reason for these decreases but this is unlikely because the basic shape reflected on the graph was reproduced as the instrument moved up and down the borehole. Moreover, no significant drift was observed in the instrument under zero flow conditions at either the start or the end of the field test. Second-order effects such as "head-loss-induced flow redistribution" (Dinwiddie et al. 1999; Flach et al. 
2000a) and hydraulic diffusivity contrasts between formation layers (Kabala 1994, Ruud and Kabala 1996, Flach et al. 2000a) can impact the EBF flow log but not to the extent observed in Figure 9.

The most likely explanation for the unexpected behavior in Figure 9 is significant variation in the fraction of the flow passing through the EBF versus bypassing the instrument, both between the skirt and well casing, and outside the screen in the filter pack annulus (Figure 7). A likely cause is that the filter pack annulus along the upper portion of the HEX-3 screen is much more conductive than at lower elevations. Changes in filter pack conductivity are thought to have caused a similar sudden reduction in flow during EBF testing at RPC-3PW (Flach et al. 2000a). Another possibility is fouling and scale buildup inside the well screen, both of which might affect the seal between the EBF rubber gasket and well screen.

Whatever the root cause, a reduction in cumulative EBF flow leads to a nonphysical, negative value for hydraulic conductivity for the interval between a depth of 26.4 and $28.4 \mathrm{ft}$, as shown in the remainder of Table 2. A negative flow rate, combined with the GEL mobile lab tritium data from Appendix A, also produces a non-physical negative value for interval mass flow rate. The results of this preliminary analysis are plotted in Figure 10. Knowing that the flow log should be non-decreasing, better estimates are achieved by interpreting what the flow rates might have been under more ideal test conditions. Under ideal conditions bypass flow is a constant fraction of total flow and the measured EBF flow is non-decreasing. One such possibility of the actual variation in borehole flow is shown in Figure 9. The corresponding hydraulic conductivity, tritium concentration, and mass flux profiles are shown in Figure 11 and Table 3. Given uncertainty in the interpretation, the revised profiles in Figure 11 should be used in a semi-quantitative manner. 
The data in Figure 11 indicate that groundwater enters the lower half of the screen at roughly three times the rate that it enters along the upper half of the screen. The variability in tritium concentration is low compared to the permeability variation. As a result, the mass flux profile follows the same trend as permeability. The shape of the concentration profile determined from EBF testing appears to be consistent with cone penetrometer testing (CPTs) conducted approximately $85 \mathrm{ft}$ upgradient of HEX-3 (Appendix B). However, the average CPT sample concentration is approximately $2,700 \mathrm{pCi} / \mathrm{mL}$ compared to $654 \mathrm{pCi} / \mathrm{mL}$ for the screen average during EBF testing, a factor of 4 difference. The concentration of groundwater samples taken from HEX-3 on September 20, 2001, was 505 $\mathrm{pCi} / \mathrm{mL}$, which is similar to the EBF results. The reason for the discrepancy between the HEX-3 sampling results and CPT is uncertain, but two plausible explanations can be offered. First, the friction ratio log for HCPT-03 indicates the CPT groundwater samples with tritium concentrations exceeding 3,000 pCi/mL came from finer-grained sediments, i.e., silts and clays (Appendix B). Such sediments have lower permeability and do not contribute much groundwater to a sample obtained after well purging or pumping has been performed. In other words, the concentration from HEX-3 is a flow-weighted average of concentrations in the formation outside the screen. A second explanation is that, despite being reasonably close (85 ft), the CPT push and HEX-3 lie on different flow paths with different tritium concentrations.

\subsection{HEX-4 Data Analysis}

EBF testing was performed on HEX-4 on February 6, 2002, between approximately 10:00 AM and 2:00 PM. The extraction system pump was shut off approximately 24 hours in advance of EBF testing. An analysis of EBF field data and laboratory sample results for HEX-4 is presented in Table 4. An initial EBF test of ambient flow conditions indicated a slight upward flow, probably corresponding to ongoing well recovery following pump shutdown the day before. 
The ambient flow rates were very small compared to dynamic testing rates. A single measurement was taken at each measurement interval. The cumulative flow profile for HEX-4 shown in Figure 12 shows none of the peculiarities observed in HEX-3. Specifically, the profile exhibits no significant decreases in low rate as the EBF advances upward. However, these observations do not preclude varying bypass flow or other problems similar to those observed with HEX-3. Relative conductivity, tritium concentration, and mass flux profiles are shown in Figure 13. Here the flow and hydraulic conductivity data show the opposite trend as HEX-3. Almost no flow enters the lower $40 \%$ of HEX-4. Like HEX-3, the tritium concentration exhibits less vertical variation than permeability, and the mass flux profile is again similar to the conductivity profile. According to EBF testing, the tritium concentration tends to increase going from the screen top to bottom. This is qualitatively consistent with the nearby CPT results listed in Appendix B. However, the well average concentration of $365 \mathrm{pCi} / \mathrm{mL}$ was again much lower during EBF testing compared to the average CPT result (Appendix B). Groundwater samples taken from HEX-4 on September 20, 2001, averaged $494 \mathrm{pCi} / \mathrm{mL}$, which is closer to the EBF sampling results. The reason for the discrepancy between the HEX-4 sampling results and CPT is uncertain. The two potential explanations offered above for HEX-3 hold for HEX-4 as well.

\subsection{HEX-18 Data Analysis}

EBF testing was performed on HEX-4 on February 11, 2002, between approximately 1:00 PM and 5:00 PM. The pump in HEX-18 was shut off approximately 8 hours in advance. Table 5 presents field and laboratory data for HEX-18. Figure 14 shows the cumulative flow log corrected for bypass flow. Like HEX-4, the cumulative flow data show an unexpected decrease in flow rate in the upper portion of the screen. Unfortunately, multiple measurements at each station were not possible due to time limitations in the field, and an instrument problem could not be ruled out. This possibility is still considered unlikely as the 
EBF showed no zero drift. Variable bypass flow is considered the most likely explanation. Conductivity, concentration, and mass flux profiles using unaltered data are presented in Figure 15. To avoid non-physical behavior in the end results, the flow data are reinterpreted in a manner similar to HEX-3 (Table 6 and Figure 14). Specifically, the cumulative flow curve was revised so that it would increase continuously along the upper portion of the screen, as shown by the dashed line. The revised estimates are presented in Figure 16.

Again, given uncertainty in the interpretation, these results should be used in a semi-qualitative manner. According to the EBF testing results, approximately $75 \%$ of the total flow comes from only a 4-ft interval near the bottom of the screen. The concentration profile shows a trend of decreasing concentration with depth, but the trend is less pronounced than the CPT results shown in Appendix B. The average well concentration during $\mathrm{EBF}$ testing was $1,770 \mathrm{pCi} / \mathrm{mL}$ compared to roughly $1,300 \mathrm{pCi} / \mathrm{mL}$ for $\mathrm{CPT}$. The agreement is good relative to the HEX-3 and -4 comparisons. The friction ratio log for HCPT-01A indicates the CPT groundwater samples of interest came from coarser-grained sediments, i.e., sands and silts. These higher permeability sediments would significantly affect groundwater samples taken after well purging or pumping had been performed.

\subsection{DISCUSSION}

The new EBF system from Century Geophysical Corporation used in HEX well testing appears to have performed well after earlier warranty repairs (Flach et al. 2001b), but instrument drift during HEX testing cannot be completely ruled out. The concept of simultaneous measurement of hydraulic conductivity, contaminant concentration, and mass flux appears to be sound. However, variable amounts of flow bypassing the borehole flowmeter apparently compromised the quality of test results from HEX wells, which are equipped with a wire-wrap screen and filter 
pack. Bypass flow by itself is not a serious problem, but rather varying amounts of bypass flow relative to total wellbore flow. The cumulative EBF flow log can be effectively corrected for a uniform fraction of bypass flow, but not for the variable amount apparent in testing at HEX-3 and -18. Therefore, the conductivity, concentration, and mass flux profiles derived at the HEX wells contain more uncertainty than desired and inherent in the technology.

\subsection{RECOMMENDATIONS}

Flow bypassing the EBF continues to compromise the effectiveness of borehole flowmeter testing. For future EBF testing, the following actions are recommended to the extent feasible to reduce bypass flow or at least to make it more uniform along the well screen:

1) Use a slotted screen rather than wire-wrap screen. The smooth inner wall of a slotted screen allows for a good seal with the EBF rubber gasket.

2) Use minimal or no filter pack. The absence of a high conductivity pathway outside the screen minimizes flow bypassing the EBF outside the well casing.

3) Consider re-developing an old well with a filter pack as a potential method of achieving a more uniform filter pack conductivity and bypass flow.

4) Inspect the inside of the well screen for fouling and scale buildup or other features that could cause variable bypass flow, and clean or swab if needed

5) Improve the design of the EBF skirt to reduce the fraction of flow bypassing the instrument inside the screen. Suggested design improvements include adding additional skirts and resizing the gasket and supporting flange diameters. 
Electromagnetic Borehole Flowmeter Testing

WSRC-TR-2002-00187

at the H-Area Extraction Wells (U)

Revision 0

Savannah River Site

May 2002

Page 13 of 37

6) Because the ideal arrangement is a slotted screen well with no filter pack, consider installing a 2" slotted screen well with CPT, letting the natural formation collapse around the screen. 


\subsection{REFERENCES}

Boman, G. K., F. J. Molz and K. D. Boone, 1997. Borehole Flowmeter Application in Fluvial Sediments: Methodology, Results, and Assessment, Ground Water, v35 n3

Controlled Notebook WSRC-NB-2001-00167

Dinwiddie, C. L., N. A. Foley and F. J. Molz, 1999. In-well Hydraulics of the Electromagnetic Borehole Flowmeter, Ground Water v37 n2, 305-315

Flach, G. P., F. C. Sappington, W. Pernell Johnson and R. A. Hiergesell, 2000a. Electromagnetic Borehole Flowmeter (EBF) Testing in R Area (U), WSRC-TR-2000-00170

Flach, G. P., F. C. Sappington, F. A. Washburn and R. A. Hiergesell, 2000 b. Electromagnetic Borehole Flowmeter (EBF) Testing at the Southwest Plume Test Pad (U), WSRC-TR-2000-00347

Flach, G. P., and A. A. Ekechukwu, 2001. Task technical and QA plan for electromagnetic borehole flowmeter testing at the H-area extraction wells (U), WSRC-TR-2001-00426, Rev. 0

Flach, G. P., W. E. Jones and F. C. Sappington, 2001. Borehole flowmeter testing at SWP-100D, Interoffice memorandum SRT-EST-2001-00322

Kabala, Z. J., 1994. Measuring distributions of hydraulic conductivity and specific storage by the double flowmeter test, Water Resources Research, v30 n3, 685-690

Molz, F. J. and S. C. Young, 1993. Development and application of borehole flowmeters for environmental assessment, The Log Analyst, v3, Jan.-Feb., 13-23 
Electromagnetic Borehole Flowmeter Testing

WSRC-TR-2002-00187

at the H-Area Extraction Wells (U)

Revision 0

Savannah River Site

May 2002

Page 15 of 37

Phifer, M. A., 1996. ESS borehole flowmeter capability, Interoffice memorandum SRT-ESS-96-453 dated October 10

Ruud, N. C., and Z. J. Kabala, 1996. Numerical evaluation of flowmeter test interpretation methodologies, Water Resources Research, v32 n4, 845-852

Technical Assistance Request, ERE-TAR-2001-0027

Waldrop, W. R., 1995. A summary of hydrogeologic studies with the Electromagnetic Borehole Flowmeter, report QEC T-102, Quantum Engineering Corporation, 112 Tigitsi Lane, Loudon, Tennessee, 37774, 615-458-0506

\subsection{APPENDIX}

Appendix A General Engineering Laboratory (GEL) Mobile Lab Tritium Analysis Results

Appendix B Nearby Cone Penetration Test Results 
Electromagnetic Borehole Flowmeter Testing

WSRC-TR-2002-00187

at the H-Area Extraction Wells (U)

Revision 0

Savannah River Site

May 2002

Page 16 of 37

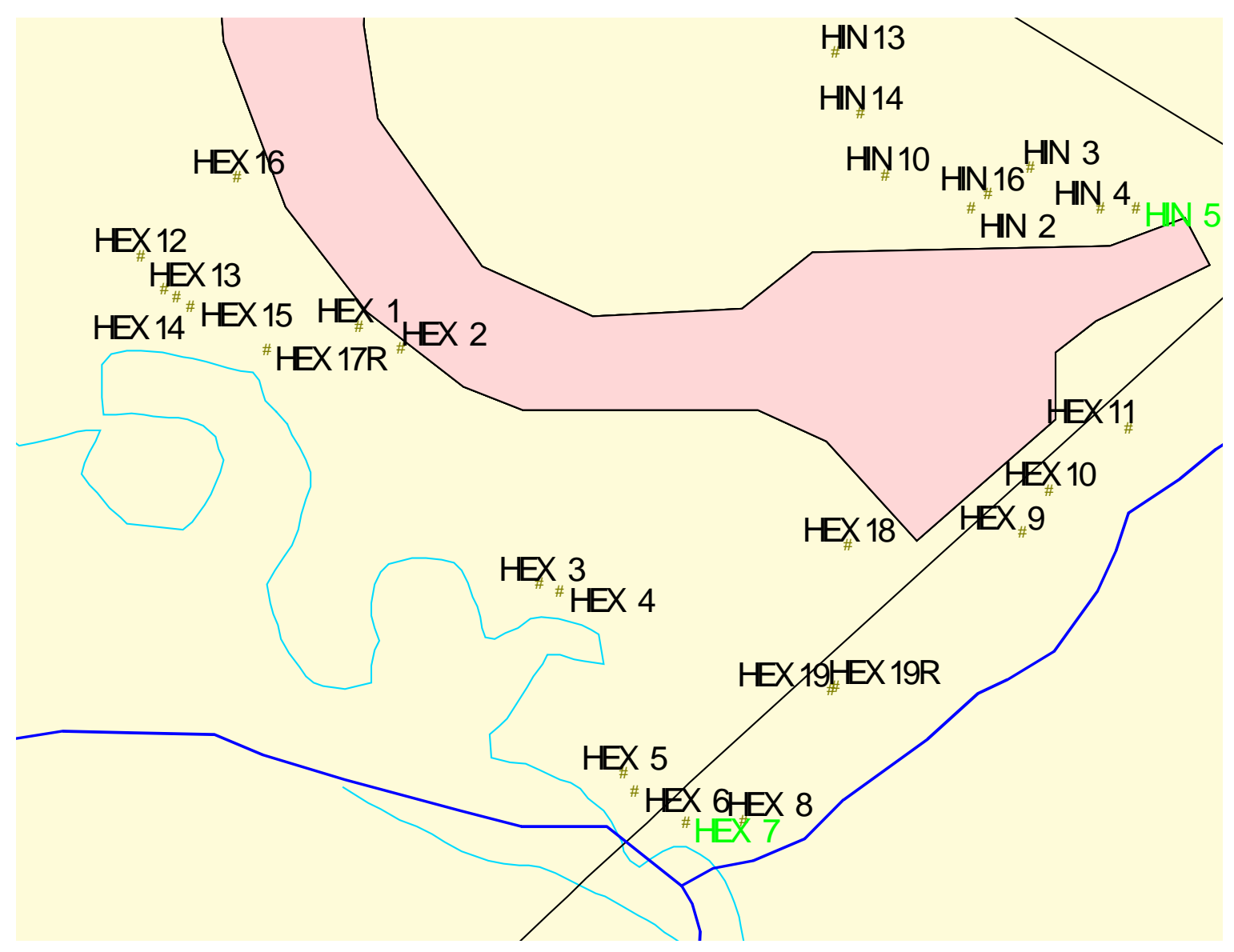

Figure 1. Locations of HEX Wells 
Electromagnetic Borehole Flowmeter Testing

at the H-Area Extraction Wells (U)

WSRC-TR-2002-00187

Savannah River Site

May 2002

Page 17 of 37

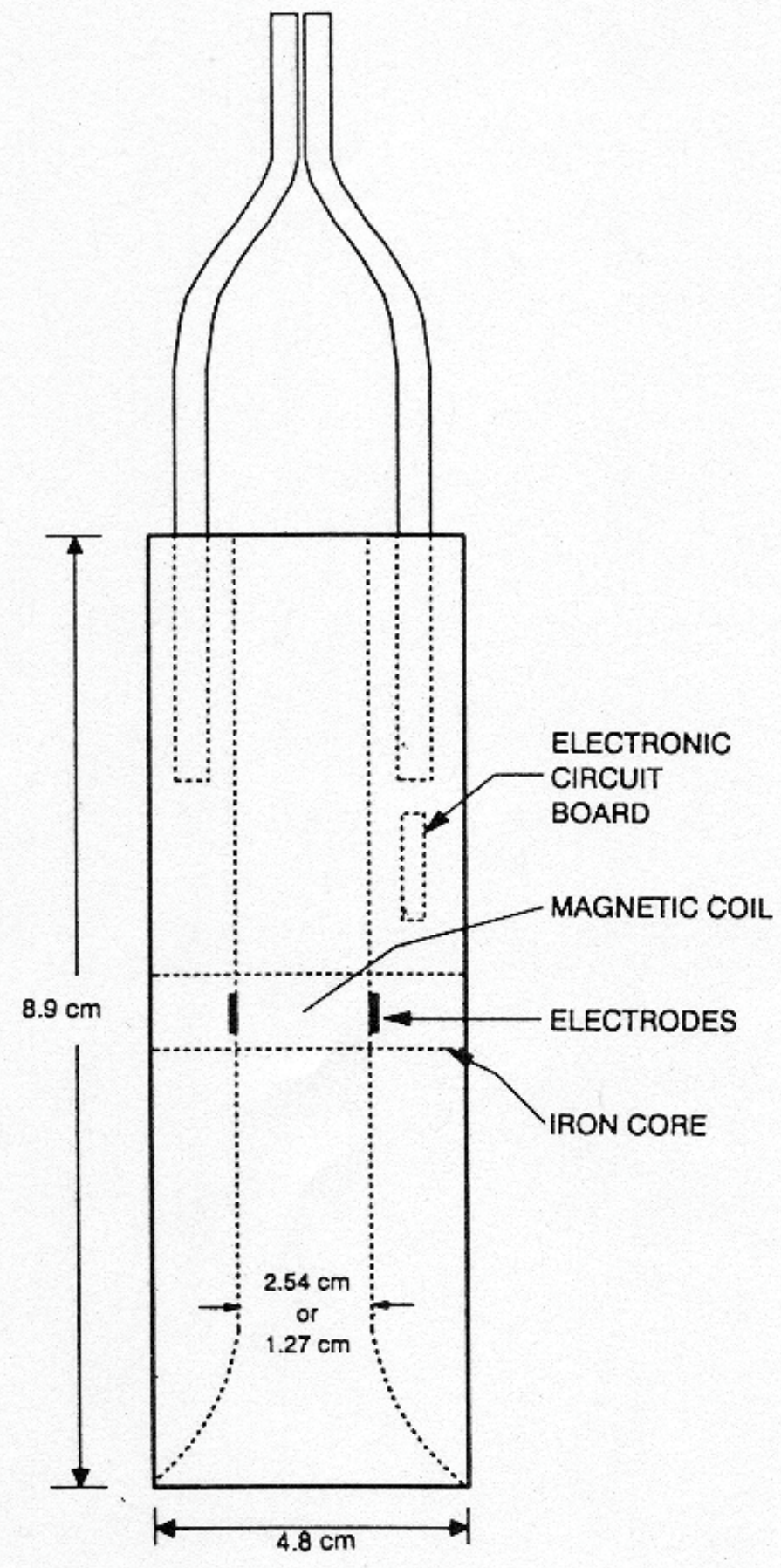

Figure 2. Schematic Diagram of the Electromagnetic Borehole Flowmeter; Reproduced from Molz and Young (1993) 
Electromagnetic Borehole Flowmeter Testing at the H-Area Extraction Wells (U)

WSRC-TR-2002-00187

Savannah River Site

May 2002

Page 18 of 37

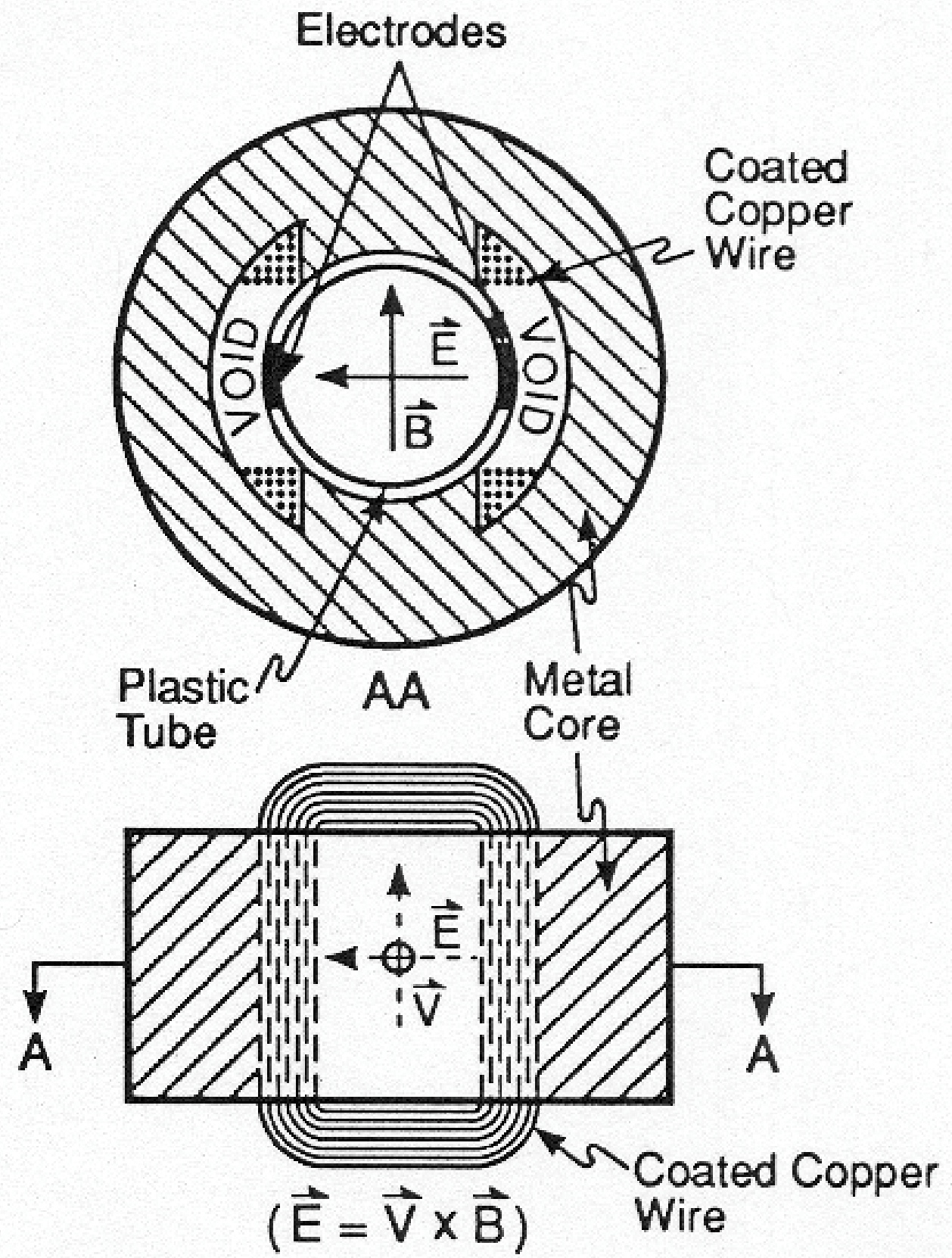

Figure 3. Electromagnetic Borehole Flowmeter (EBF) Application of Faraday's Law of Induction; Reproduced from Molz and Young (1993) 
Electromagnetic Borehole Flowmeter Testing at the H-Area Extraction Wells (U)

WSRC-TR-2002-00187

Savannah River Site

May 2002

Page 19 of 37

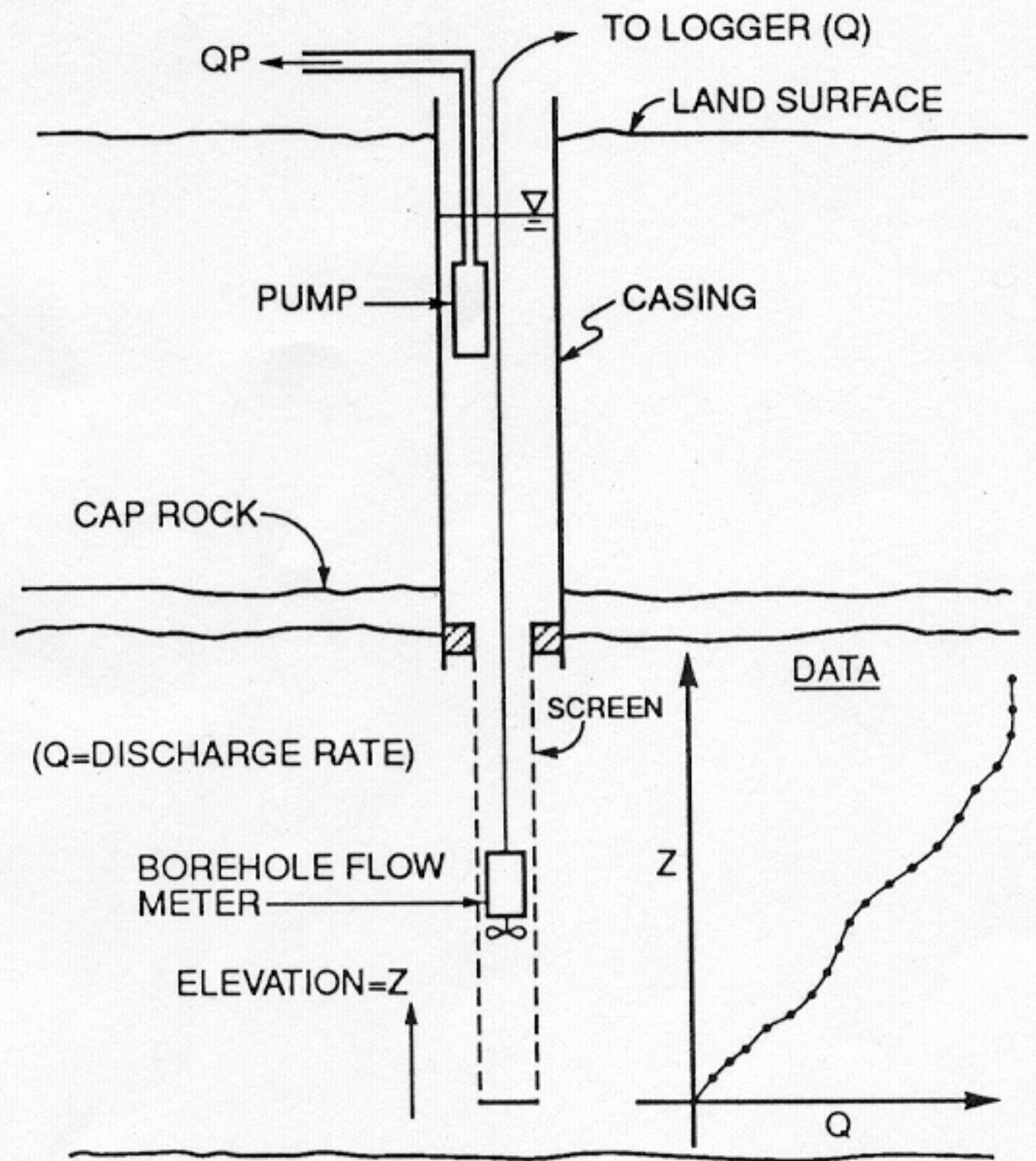

Figure 4. Schematic Illustration of Borehole Flowmeter Testing; Reproduced from Molz and Young (1993) 
Electromagnetic Borehole Flowmeter Testing

WSRC-TR-2002-00187

at the H-Area Extraction Wells (U)

Revision 0

Savannah River Site

May 2002

Page 20 of 37

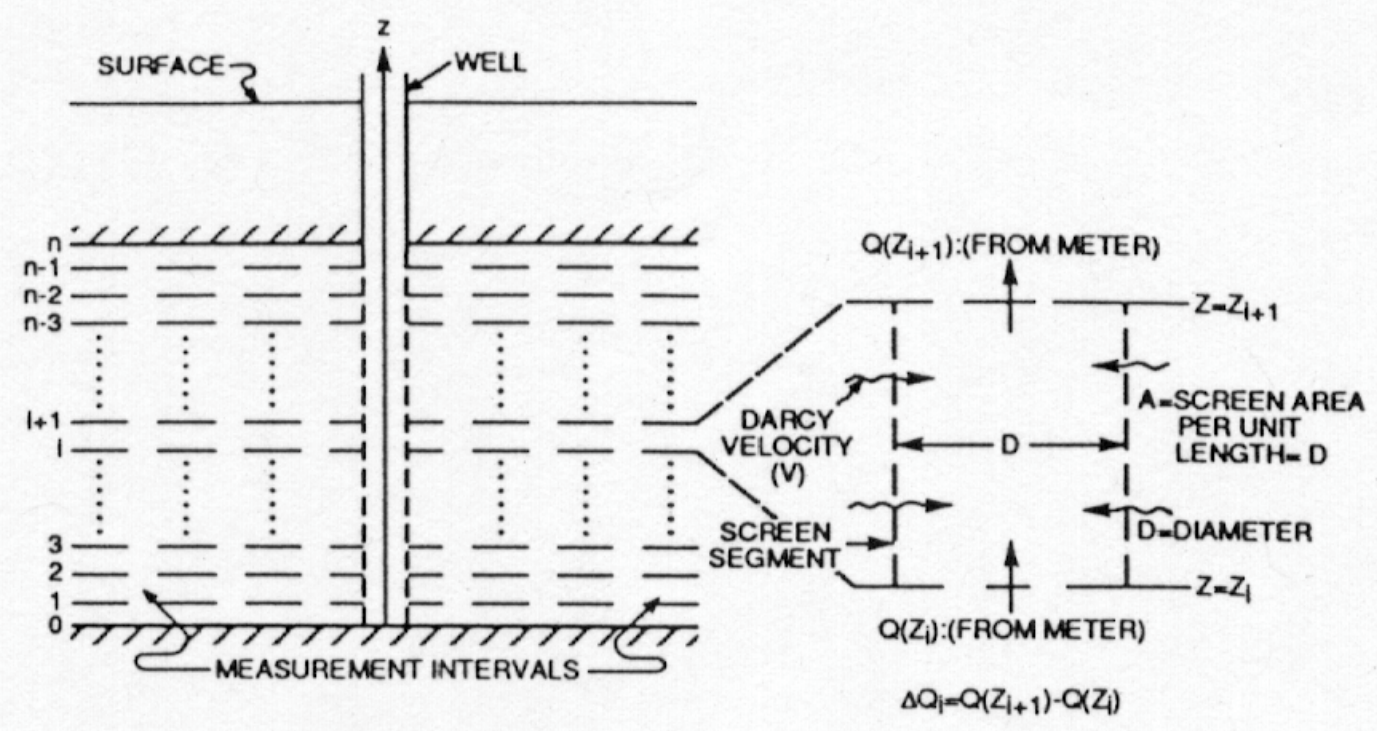

Figure 5. Basic Geometry and Analysis of Borehole Flowmeter Data; Reproduced from Molz and Young (1993) 
Electromagnetic Borehole Flowmeter Testing at the H-Area Extraction Wells (U)

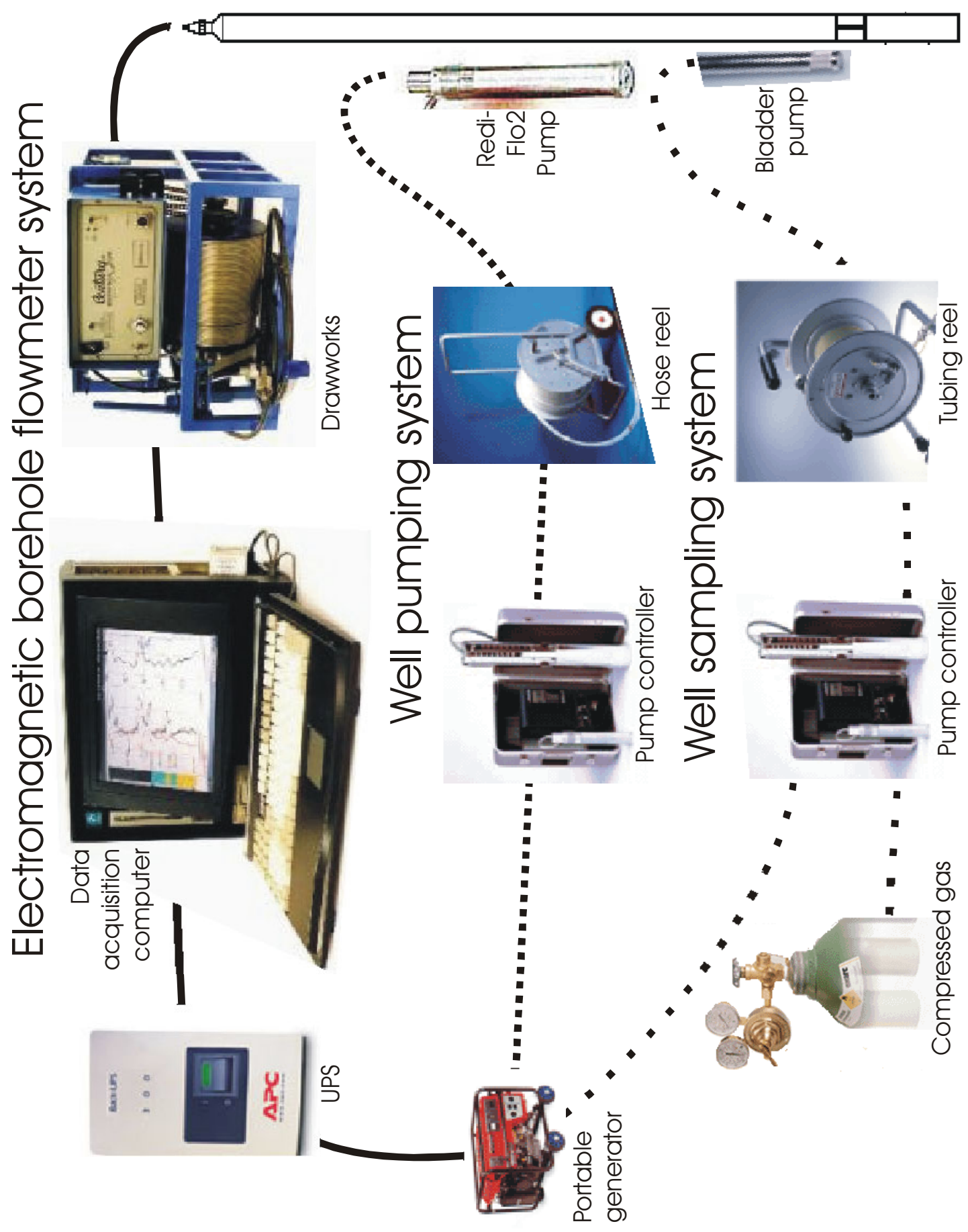

Figure 6. Configuration of Primary Test Equipment 
Electromagnetic Borehole Flowmeter Testing

WSRC-TR-2002-00187

at the H-Area Extraction Wells (U)

Revision 0

Savannah River Site

May 2002

Page 22 of 37
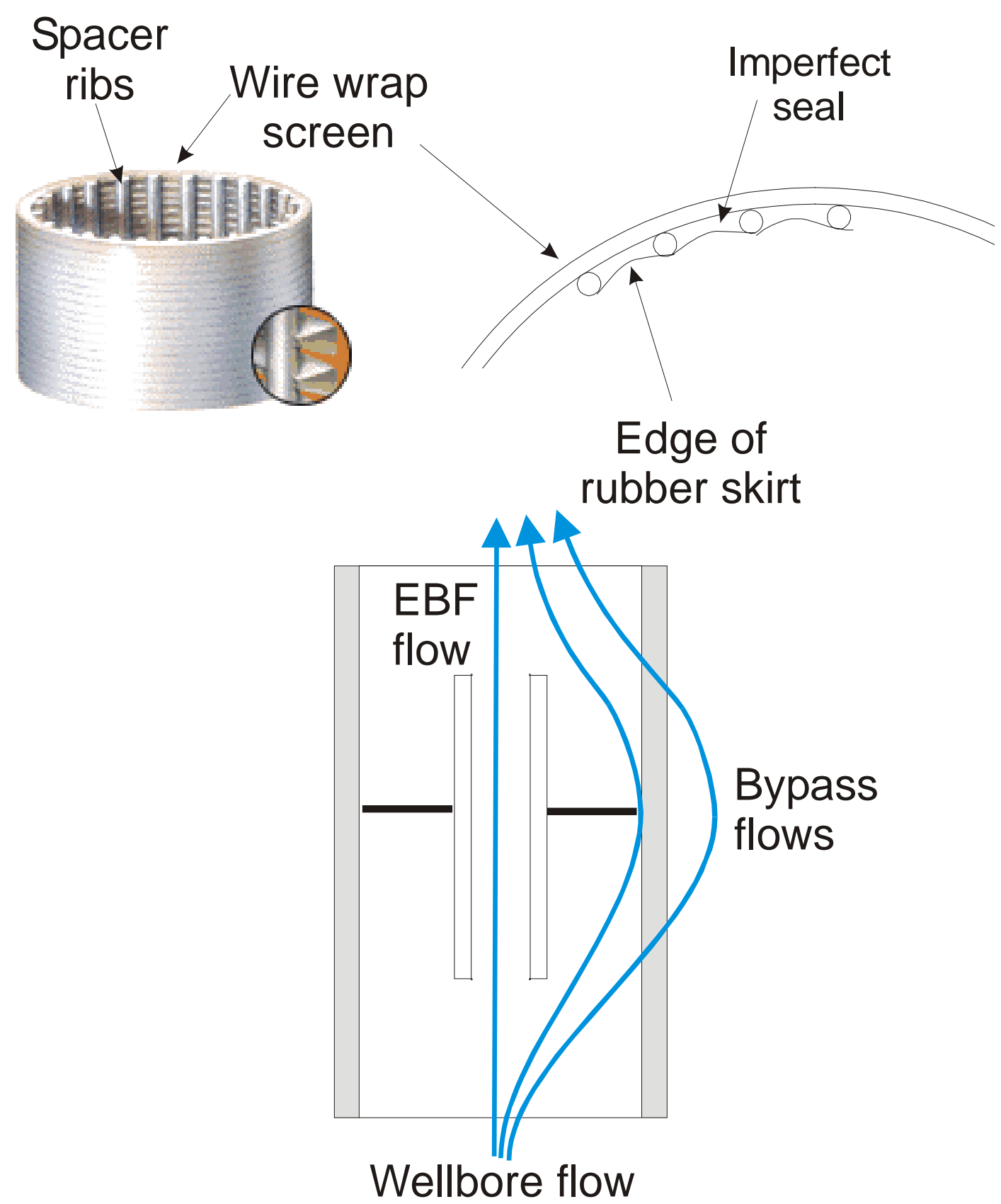

Figure 7. Wire-Wrap Screen Construction and Bypass Flow Phenomenon 
Electromagnetic Borehole Flowmeter Testing

WSRC-TR-2002-00187

at the H-Area Extraction Wells (U)

Revision 0

Savannah River Site

May 2002

Page 23 of 37

HEX-3

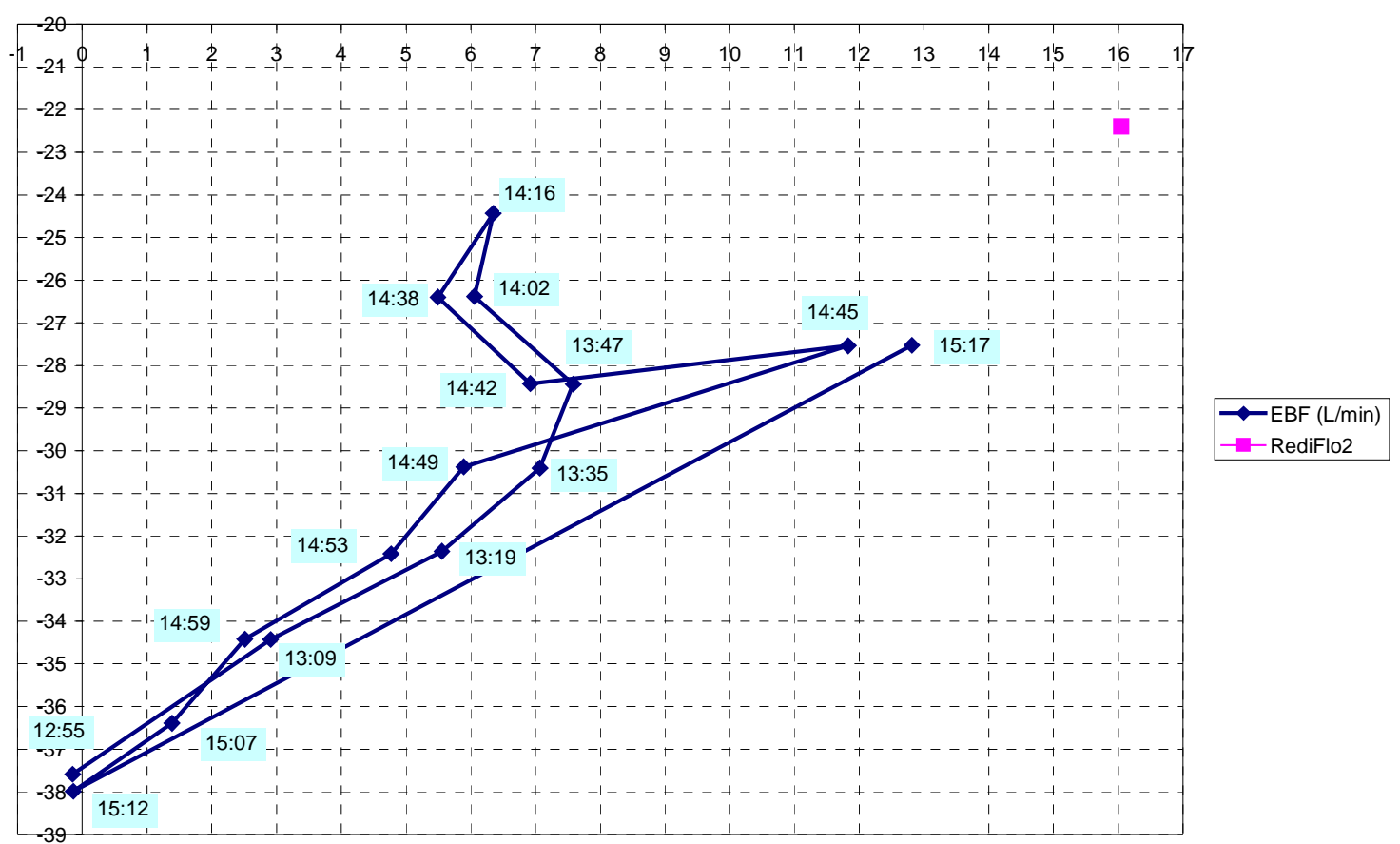

Depth EBF (L/min)

$37.59 \quad-0.149$

$34.43 \quad 2.908$

$32.36 \quad 5.553$

$30.41 \quad 7.067$

$28.44 \quad 7.582$

$26.38 \quad 6.056$

$24.43 \quad 6.346$

$26.4 \quad 5.494$

$28.43 \quad 6.921$

$27.54 \quad 11.831$

$30.38 \quad 5.891$

$32.42 \quad 4.771$

$34.42 \quad 2.508$

$36.39 \quad 1.383$

$37.99-0.14$

$27.53 \quad 12.814$

$22.4 \quad 16.047$

Figure 8. Raw Flow Data for HEX-3 
Electromagnetic Borehole Flowmeter Testing

WSRC-TR-2002-00187

at the H-Area Extraction Wells (U)

Revision 0

Savannah River Site

May 2002

Page 24 of 37

HEX-3

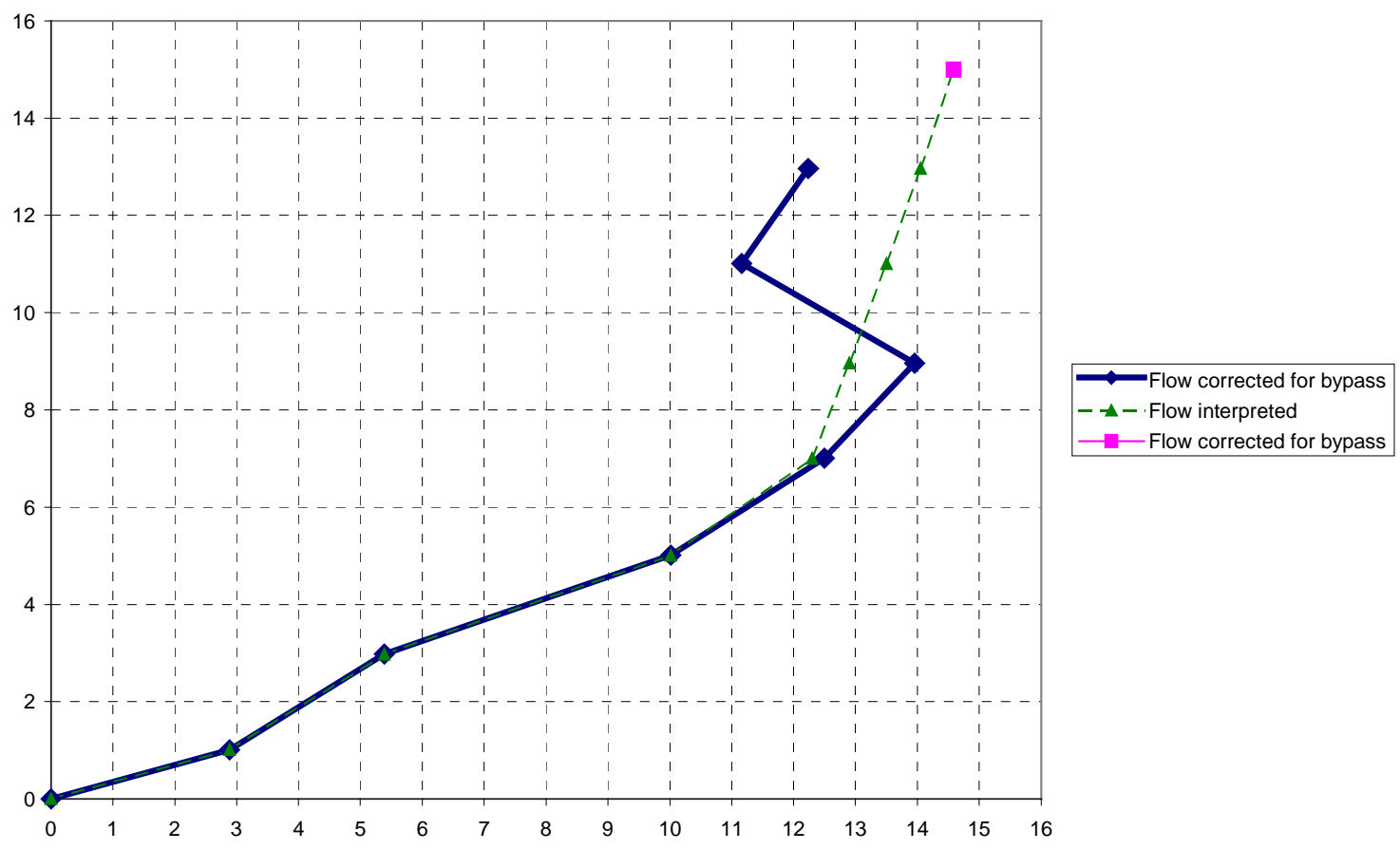

Figure 9. Cumulative Flow Logs for HEX-3, Preliminary and Interpreted 
Electromagnetic Borehole Flowmeter Testing

WSRC-TR-2002-00187

at the H-Area Extraction Wells (U)

Revision 0

Savannah River Site

May 2002

Page 25 of 37

HEX-3
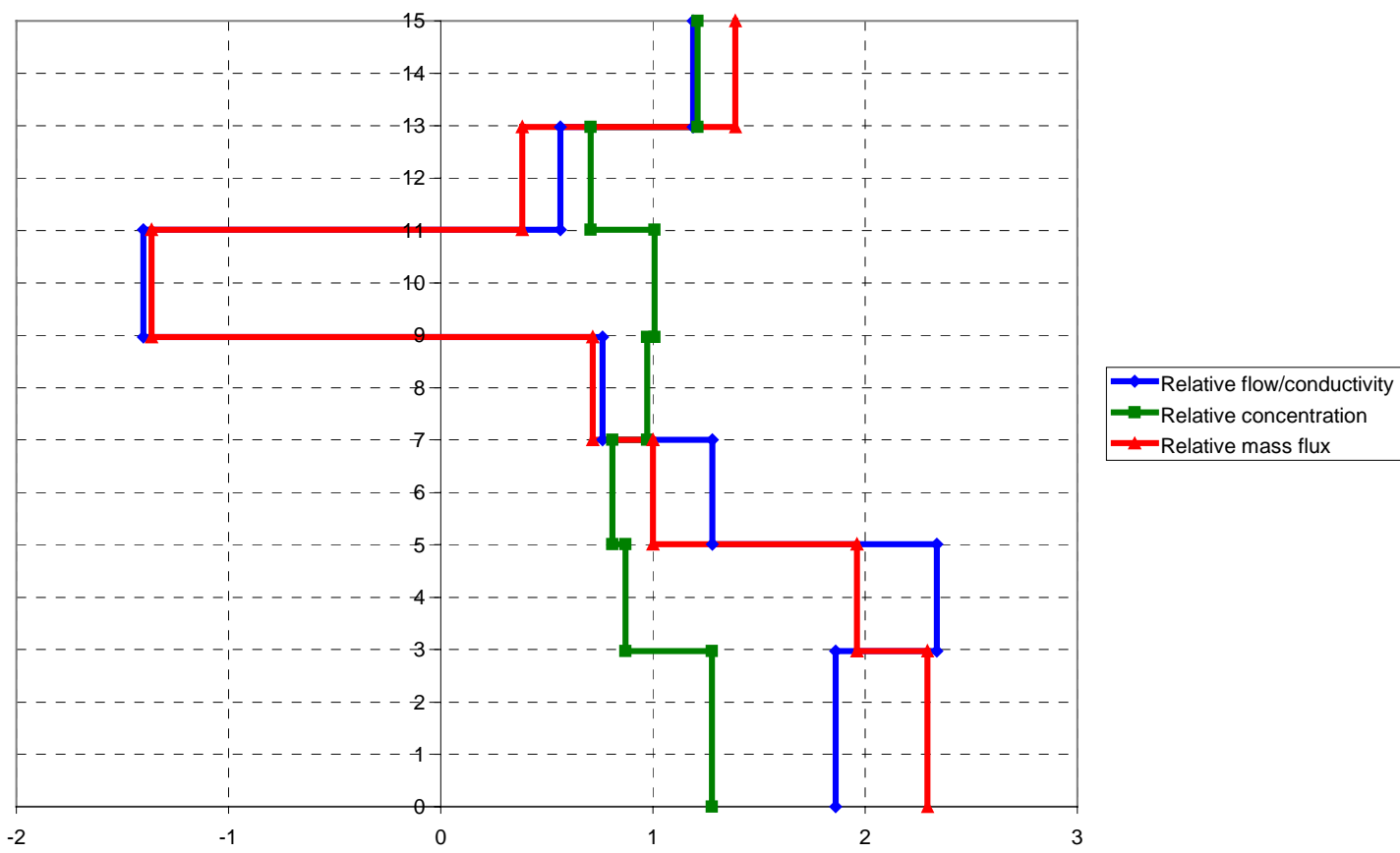

Figure 10. Preliminary Estimates of Hydraulic Conductivity, Tritium Concentration and Mass Flux, Referenced to Screen Average Values for HEX-3 
Electromagnetic Borehole Flowmeter Testing

WSRC-TR-2002-00187

at the H-Area Extraction Wells (U)

Revision 0

Savannah River Site

May 2002

Page 26 of 37

HEX-3

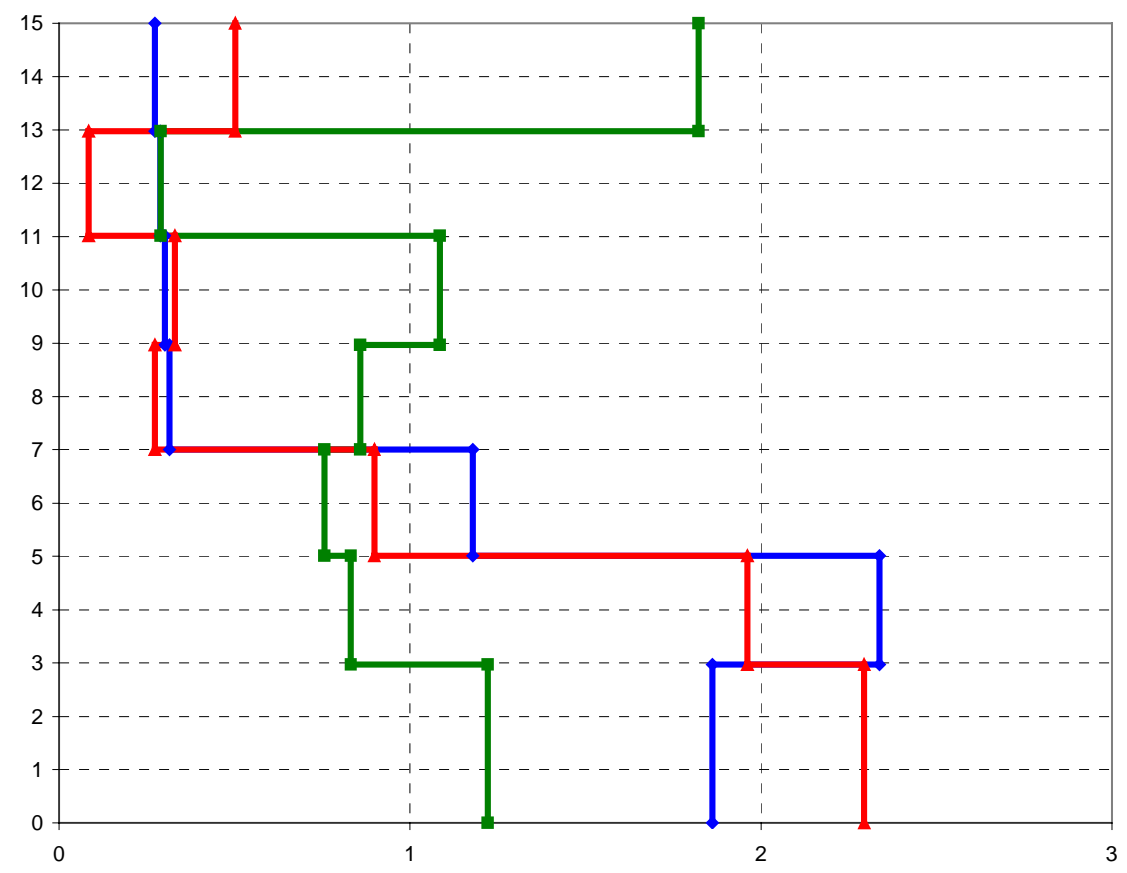

$\rightarrow$ Relative flow/conductivity

- Relative concentration - Relative mass flux

Figure 11. Revised Estimates of Hydraulic Conductivity, Tritium Concentration and Mass Flux, Referenced to Screen Average Values for HEX-3 
Electromagnetic Borehole Flowmeter Testing

WSRC-TR-2002-00187

at the H-Area Extraction Wells (U)

Revision 0

Savannah River Site

May 2002

Page 27 of 37

HEX-4

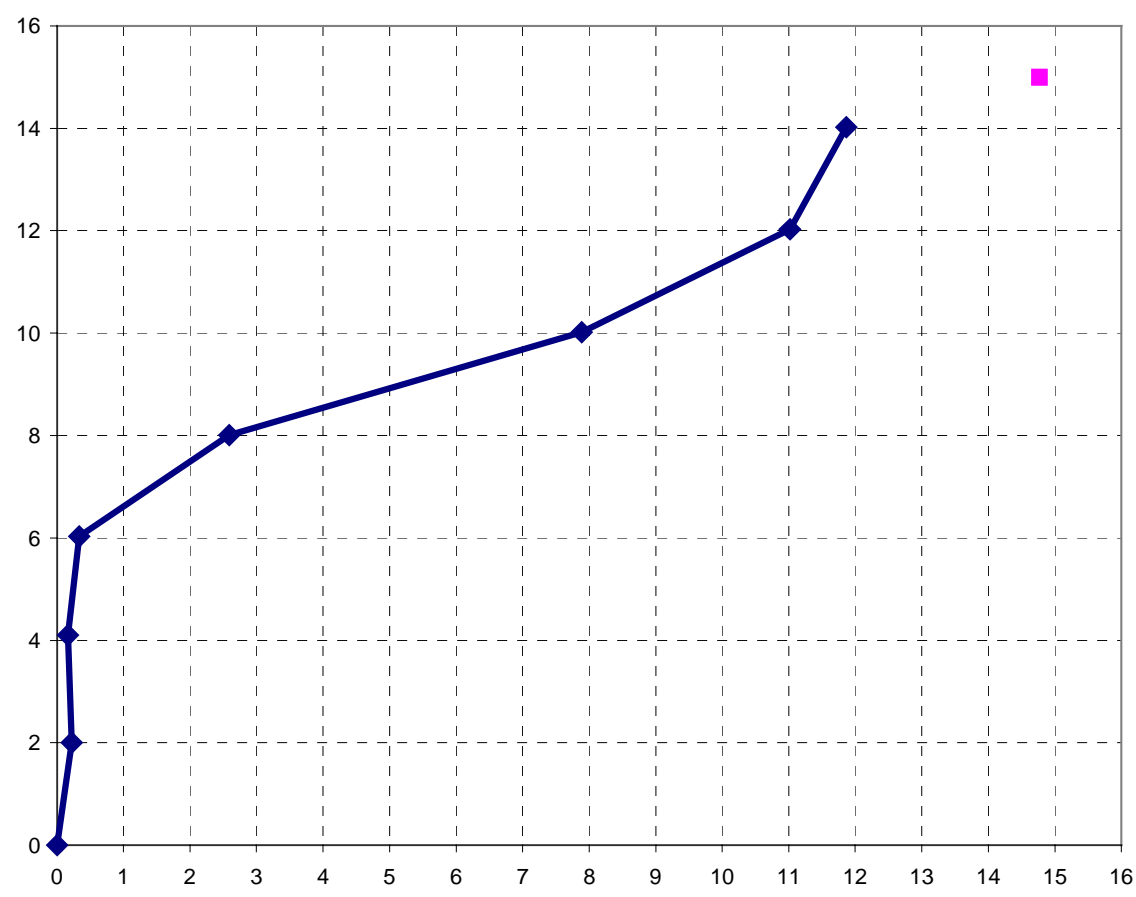

-Flow corrected for bypass -Flow corrected for bypass

Figure 12. Cumulative Flow Log for HEX-4 
Electromagnetic Borehole Flowmeter Testing

WSRC-TR-2002-00187

at the H-Area Extraction Wells (U)

Revision 0

Savannah River Site

May 2002

Page 28 of 37

HEX-4

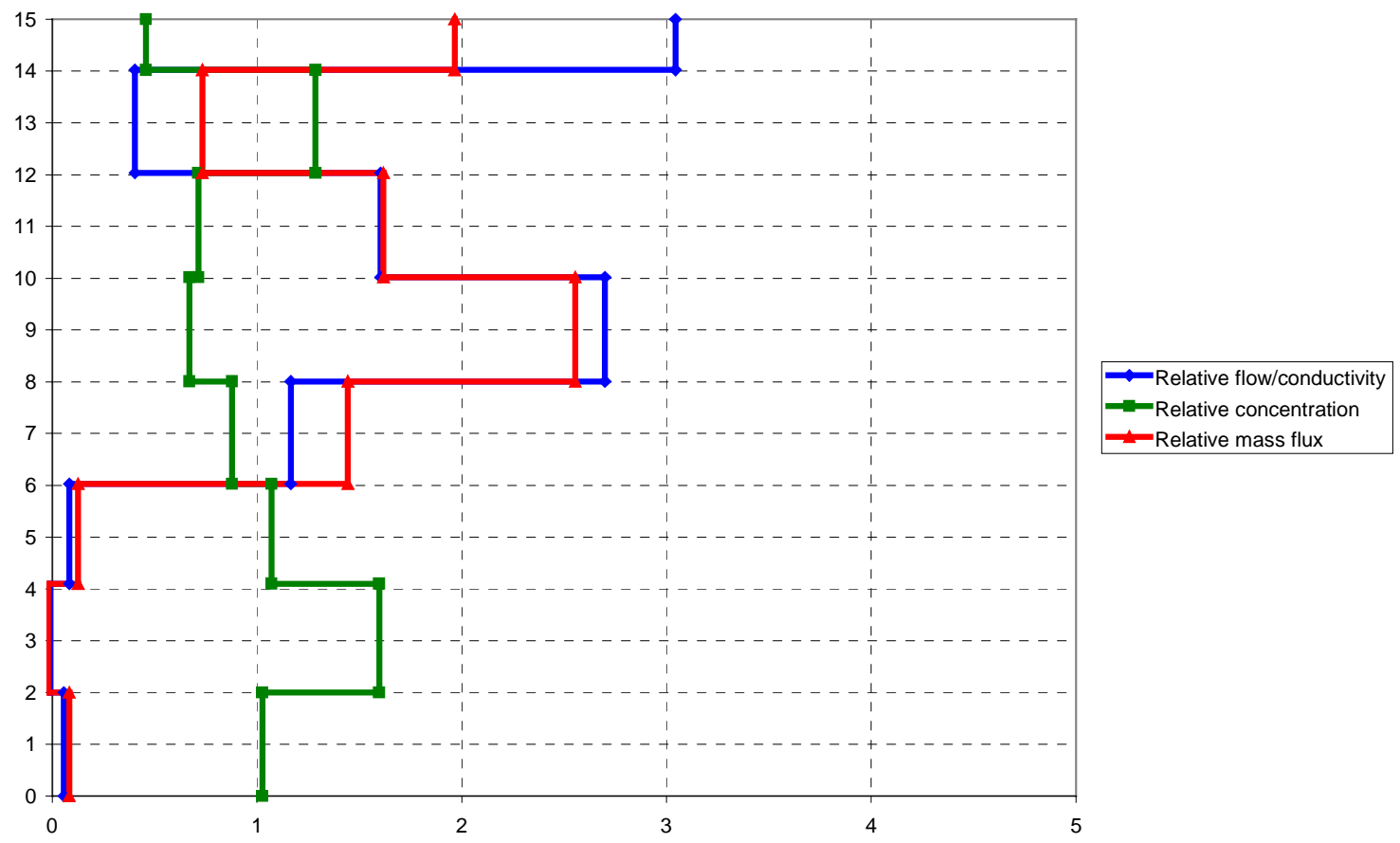

Figure 13. Estimates of Hydraulic Conductivity, Tritium Concentration and Mass Flux, Referenced to Screen Average Values for HEX-4 
Electromagnetic Borehole Flowmeter Testing

at the H-Area Extraction Wells (U)

WSRC-TR-2002-00187

Savannah River Site

May 2002

Page 29 of 37

HEX-18

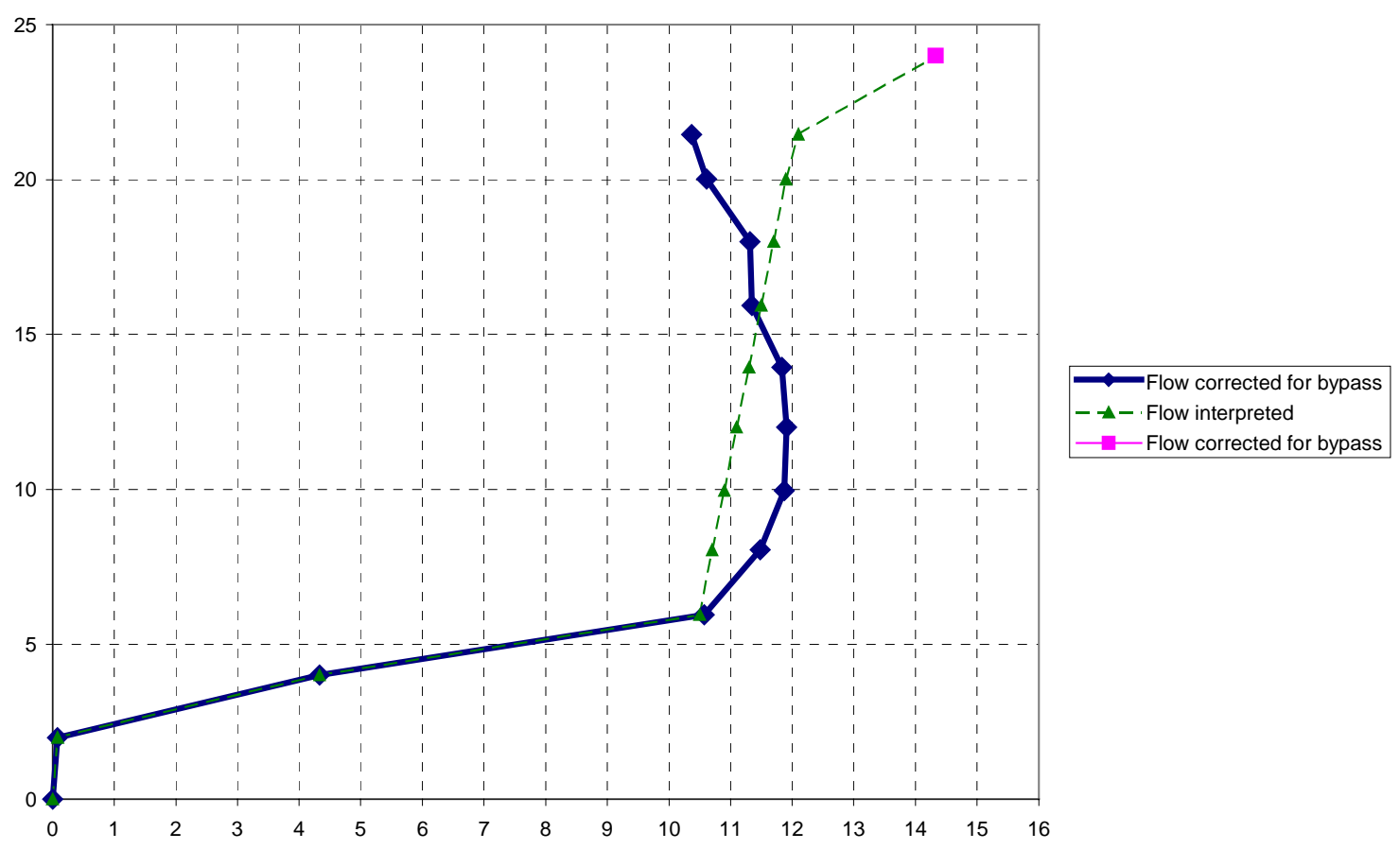

Figure 14. Cumulative Flow Logs for HEX-18, Preliminary and Interpreted 
Electromagnetic Borehole Flowmeter Testing

WSRC-TR-2002-00187

at the H-Area Extraction Wells (U)

Revision 0

Savannah River Site

May 2002

Page 30 of 37

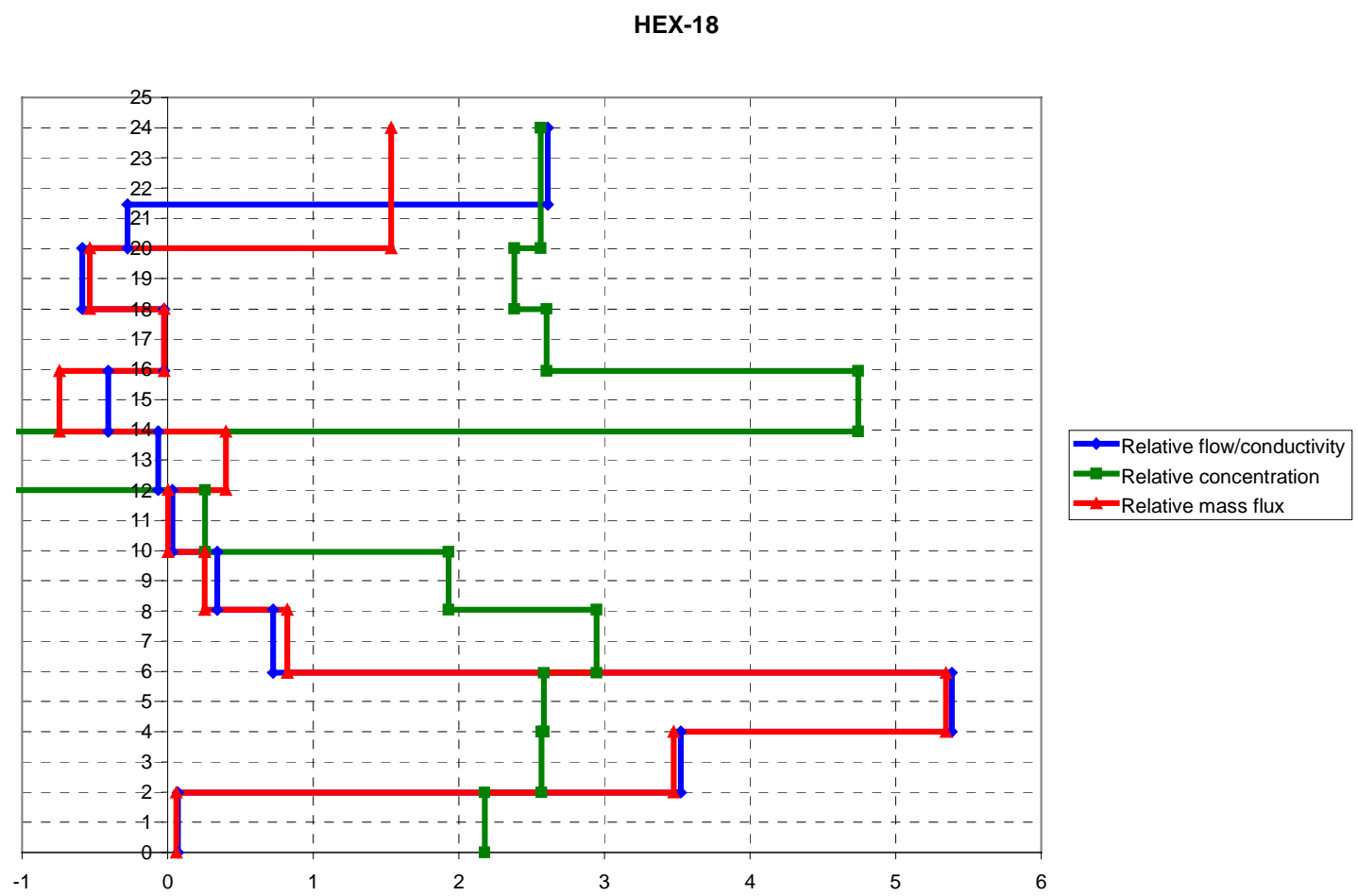

Figure 15. Preliminary Estimates of Hydraulic Conductivity, Tritium Concentration and Mass Flux, Referenced to Screen Average Values for HEX-18 
Electromagnetic Borehole Flowmeter Testing

WSRC-TR-2002-00187

at the H-Area Extraction Wells (U)

Revision 0

Savannah River Site

May 2002

Page 31 of 37

HEX-18

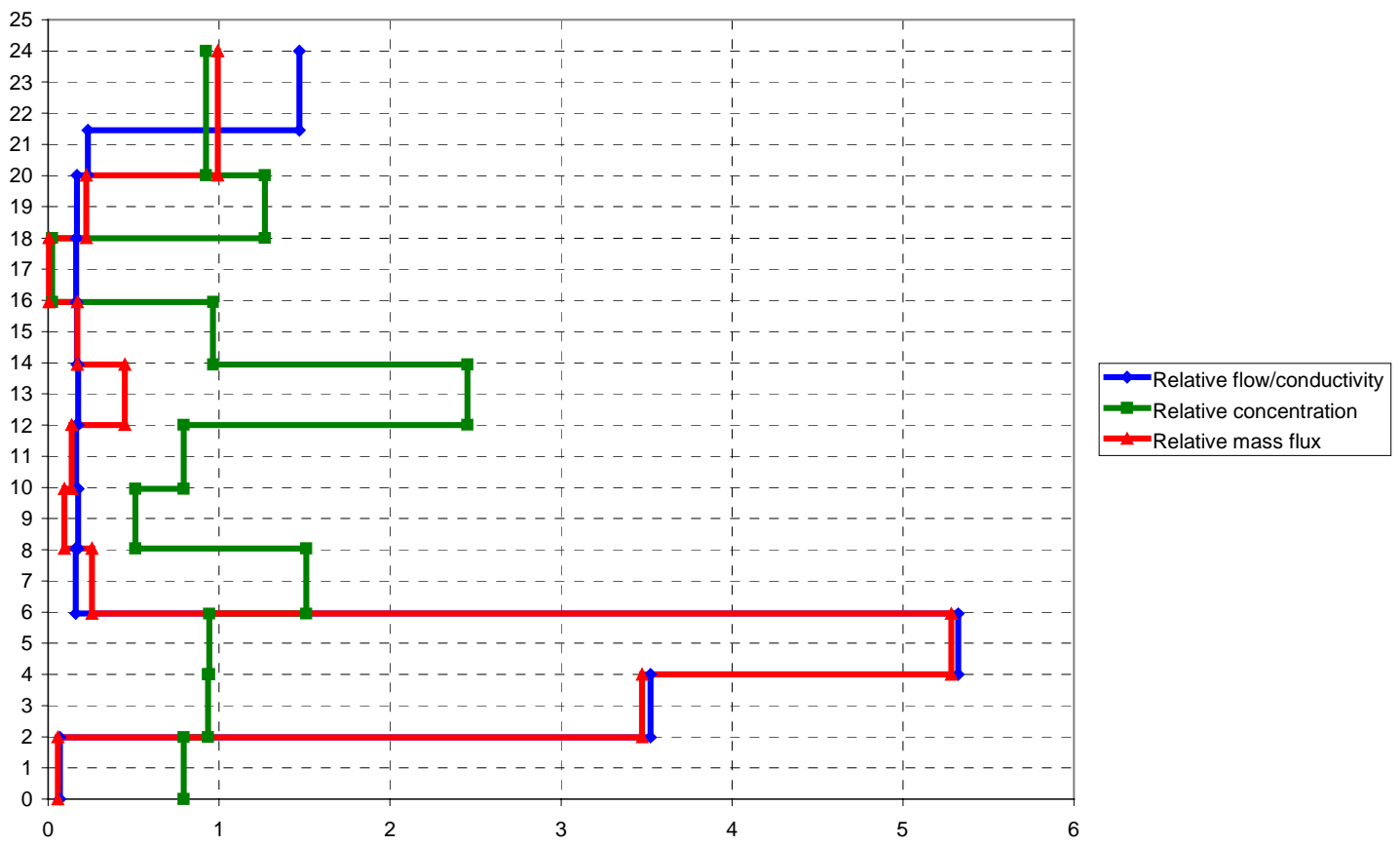

Figure 16. Revised Estimates of Hydraulic Conductivity, Tritium Concentration and Mass Flux, Referenced to Screen Average Values for HEX-18 
Electromagnetic Borehole Flowmeter Testing

WSRC-TR-2002-00187

at the H-Area Extraction Wells (U)

Revision 0

\section{Savannah River Site}

May 2002

Page 32 of 37

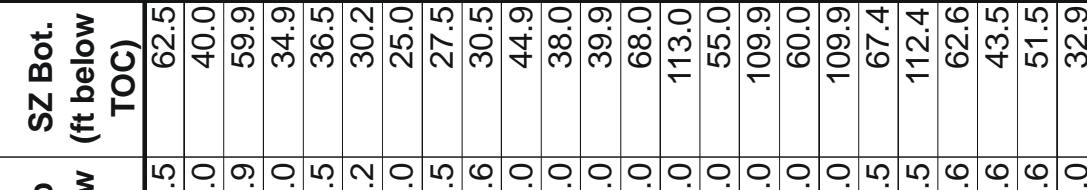

응 o o N่是

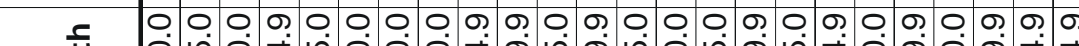

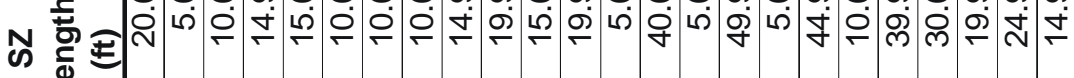
๑

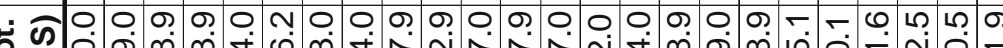

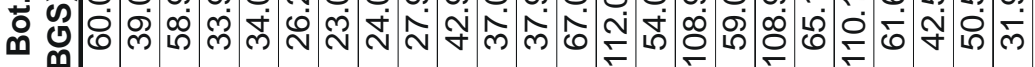
ヘ \pm

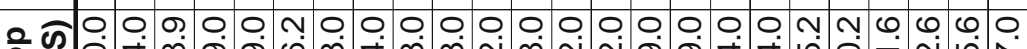
○ J্ল N

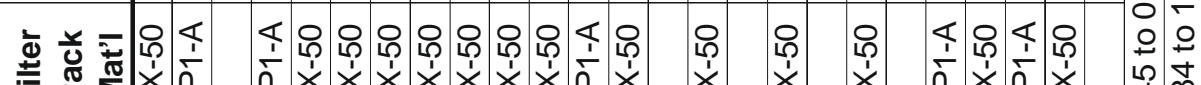

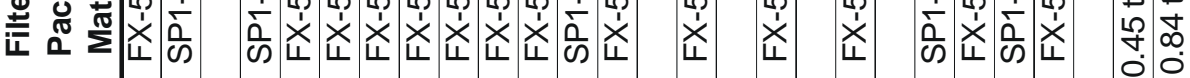

\begin{tabular}{|c|c|c|c|c|c|c|c|c|c|c|c|}
\hline 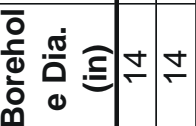 & $\underset{ர}{\forall}$ & & & 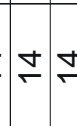 & & $\Xi$ & 7 & & $\forall$ & $\stackrel{\nabla}{\sim}$ & 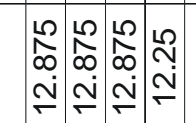 \\
\hline
\end{tabular}

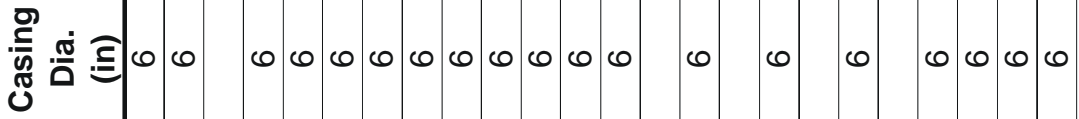

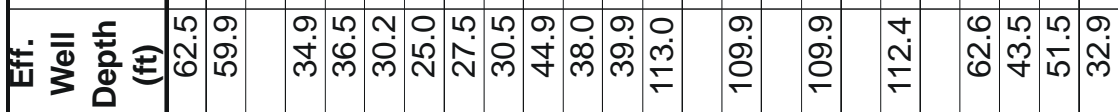

\begin{tabular}{|c|c|c|c|c|c|c|c|c|c|c|c|c|c|c|}
\hline O & 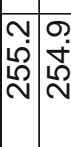 & 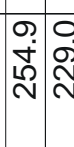 & 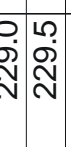 & \begin{tabular}{l|l}
$\infty$ & - \\
$\stackrel{\omega}{\infty}$ & $\frac{m}{\sim}$ \\
\end{tabular} & 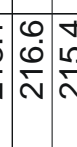 & 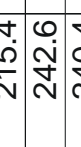 & 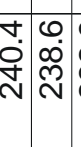 & 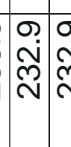 & 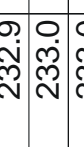 & 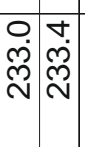 & 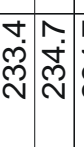 & \begin{tabular}{l|l} 
\\
$\stackrel{N}{\sim}$
\end{tabular} & 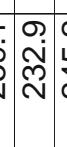 & 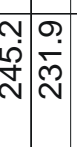 \\
\hline 巳 & సָ సి & & $\begin{array}{ll}0 \\
D \\
N\end{array}$ & 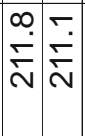 & 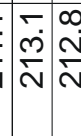 & 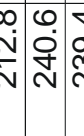 & 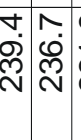 & 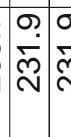 & 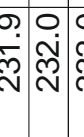 & 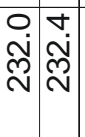 & 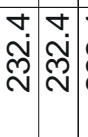 & 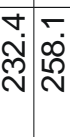 & 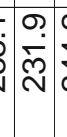 & 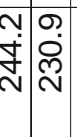 \\
\hline 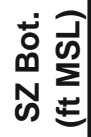 & 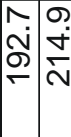 & مُ & 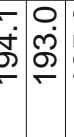 & \begin{tabular}{l|l}
$\mathscr{0}$ & - \\
$\stackrel{\rho}{0}$ & $\infty$ \\
$\infty$ & $\infty$ \\
& -
\end{tabular} & \begin{tabular}{ll}
$\widetilde{\sigma}$ \\
$\mathscr{\infty}$ \\
\hdashline \\
\hdashline \\
\hdashline
\end{tabular} & 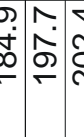 & 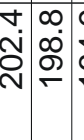 & $\mid$\begin{tabular}{ll}
0 & 0 \\
$\dot{\theta}$ & 0 \\
\hdashline & $\gamma$
\end{tabular} & 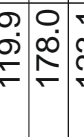 & 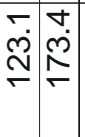 & 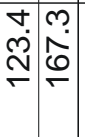 & 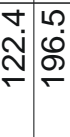 & 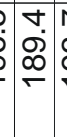 & 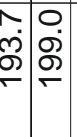 \\
\hline 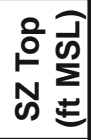 & \begin{tabular}{l|l}
$\hat{N}$ \\
$\stackrel{a}{N}$ & $\frac{D}{N}$ \\
\end{tabular} & 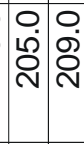 & 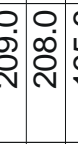 & 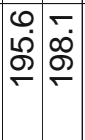 & Г̊ & 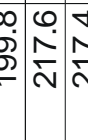 & 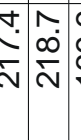 & 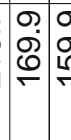 & 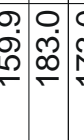 & 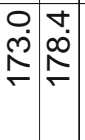 & 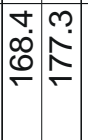 & 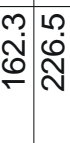 & $\begin{array}{l}m \\
\dot{D} \\
\dot{\Omega}\end{array}$ & 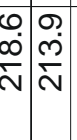 \\
\hline $\begin{array}{l}\text { 으 } \\
\overline{\overline{0}} \\
\text { 亏े }\end{array}$ & $\begin{array}{ll}- & \sim \\
x & x \\
\dddot{\Psi} & \end{array}$ & $\begin{array}{l}m \\
\times \\
\ddot{I}\end{array}$ & 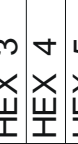 & & & 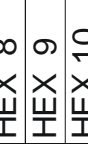 & & & $\begin{array}{l}m \\
\stackrel{m}{x} \\
\underset{I}{\Psi}\end{array}$ & 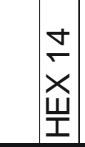 & 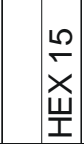 & 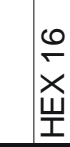 & 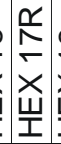 & 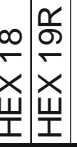 \\
\hline
\end{tabular}

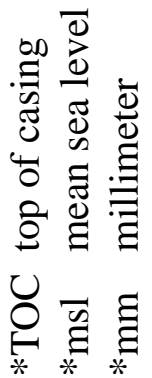

Table 1. Well Construction Information for HEX Wells 
Electromagnetic Borehole Flowmeter Testing

at the H-Area Extraction Wells (U)

WSRC-TR-2002-00187

Savannah River Site

May 2002

Page 33 of 37

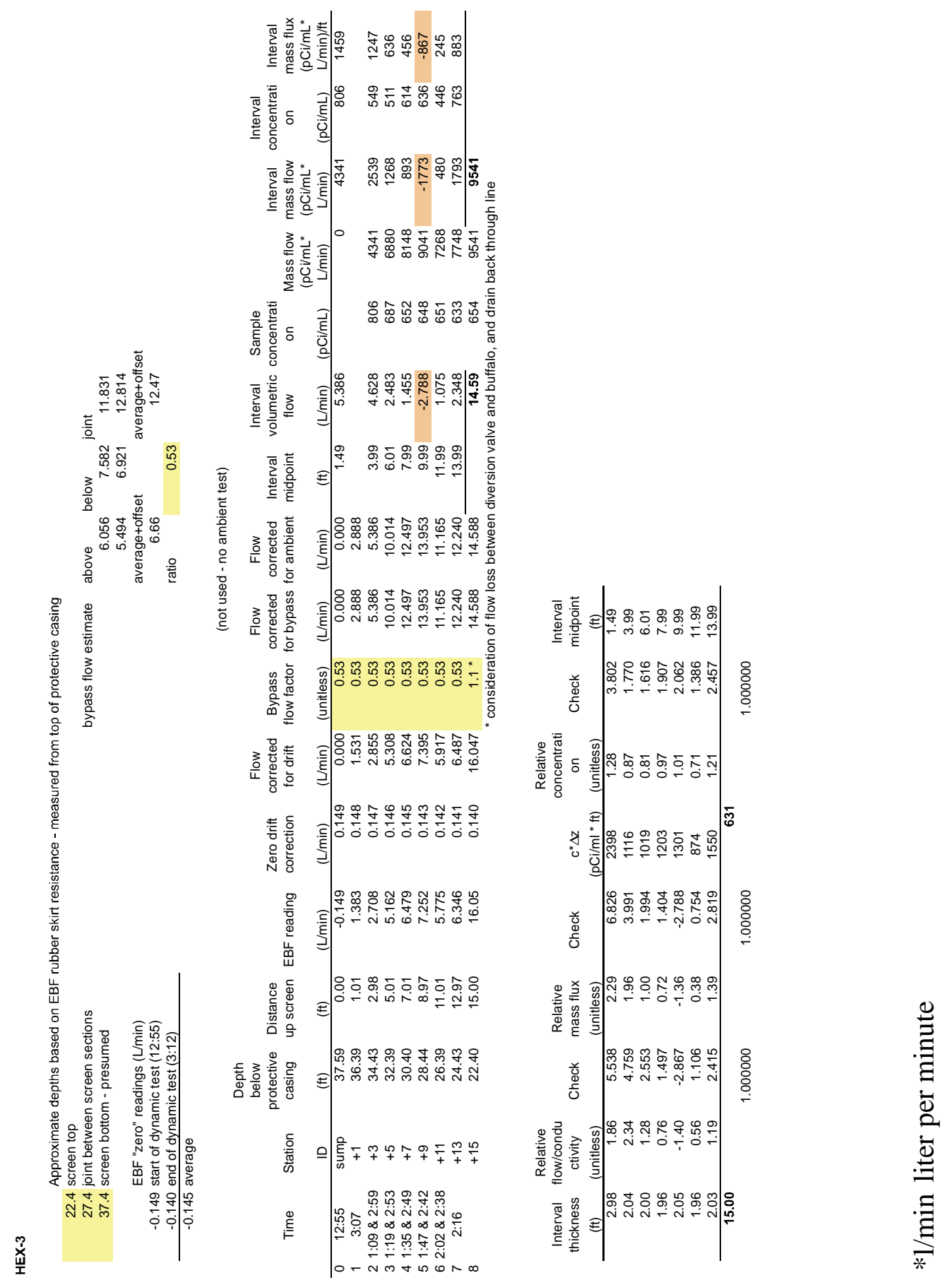

Table 2. Preliminary Data Analysis for HEX-3 
Electromagnetic Borehole Flowmeter Testing

WSRC-TR-2002-00187

at the H-Area Extraction Wells (U)

Revision 0

Savannah River Site

May 2002

Page 34 of 37

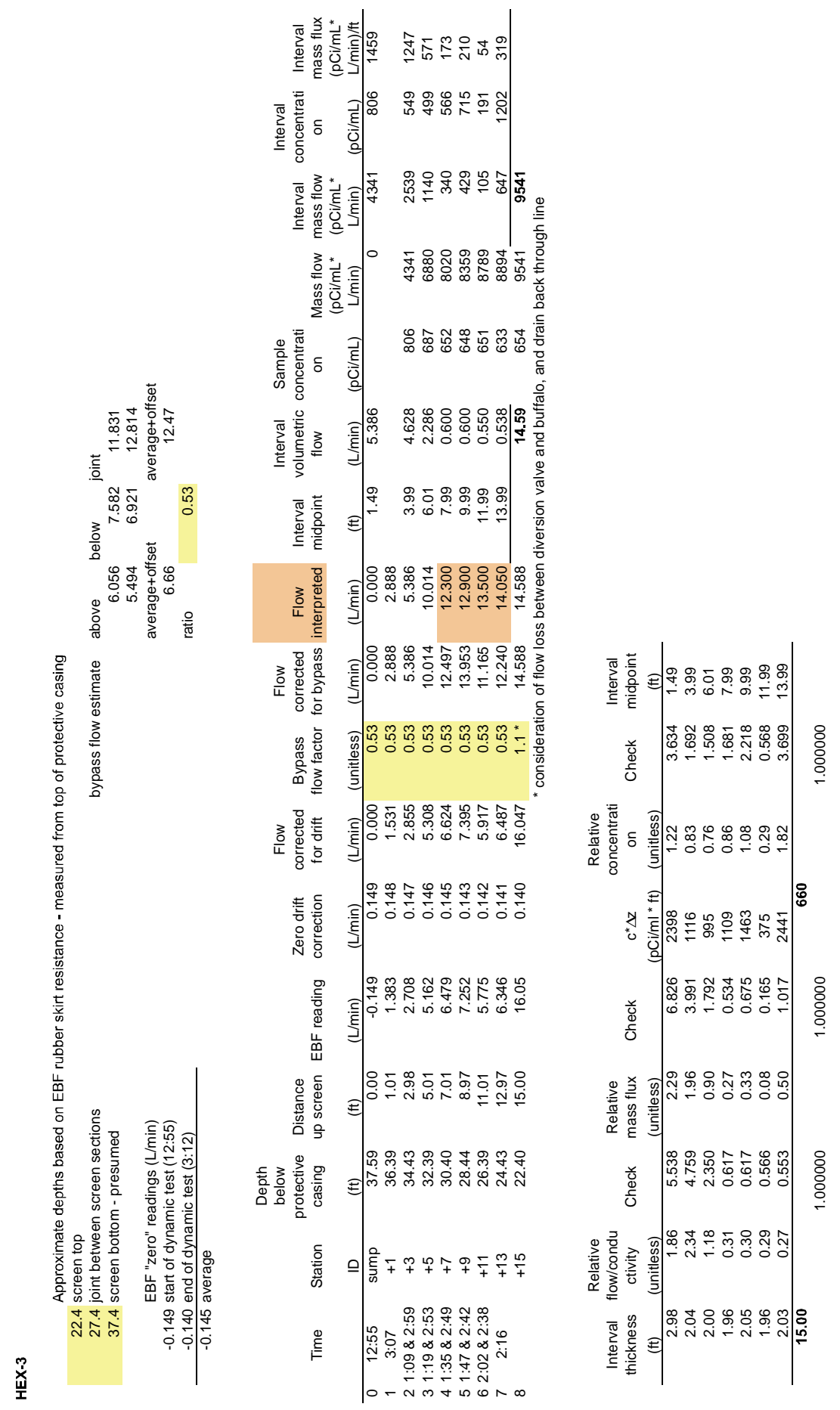

Table 3. Revised Data Analysis for HEX-3 
Electromagnetic Borehole Flowmeter Testing

WSRC-TR-2002-00187

at the H-Area Extraction Wells (U)

Revision 0

Savannah River Site

May 2002

Page 35 of 37

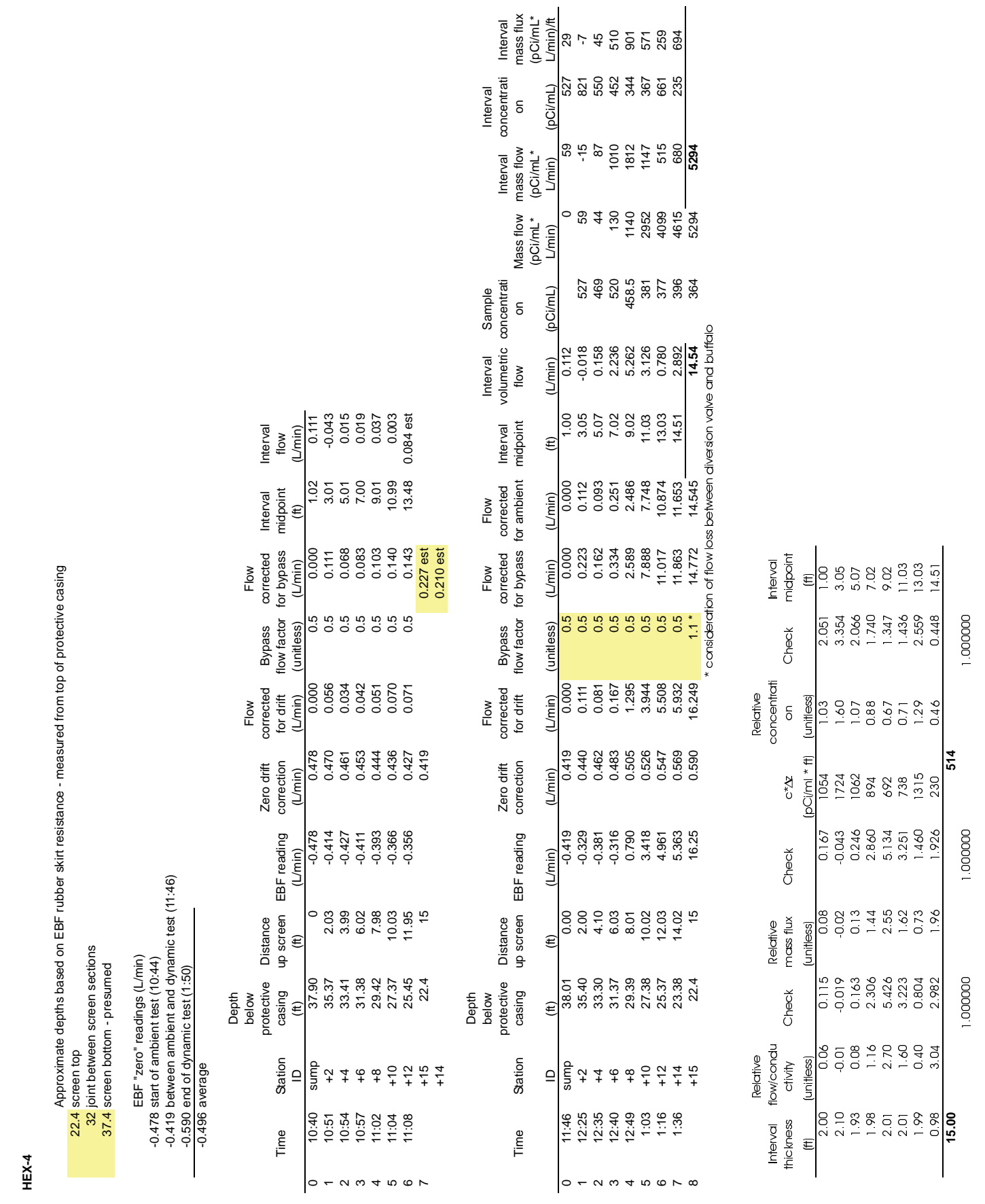

Table 4. Data Analysis for HEX-4 
Electromagnetic Borehole Flowmeter Testing

WSRC-TR-2002-00187

at the H-Area Extraction Wells (U)

Revision 0

Savannah River Site

May 2002

Page 36 of 37

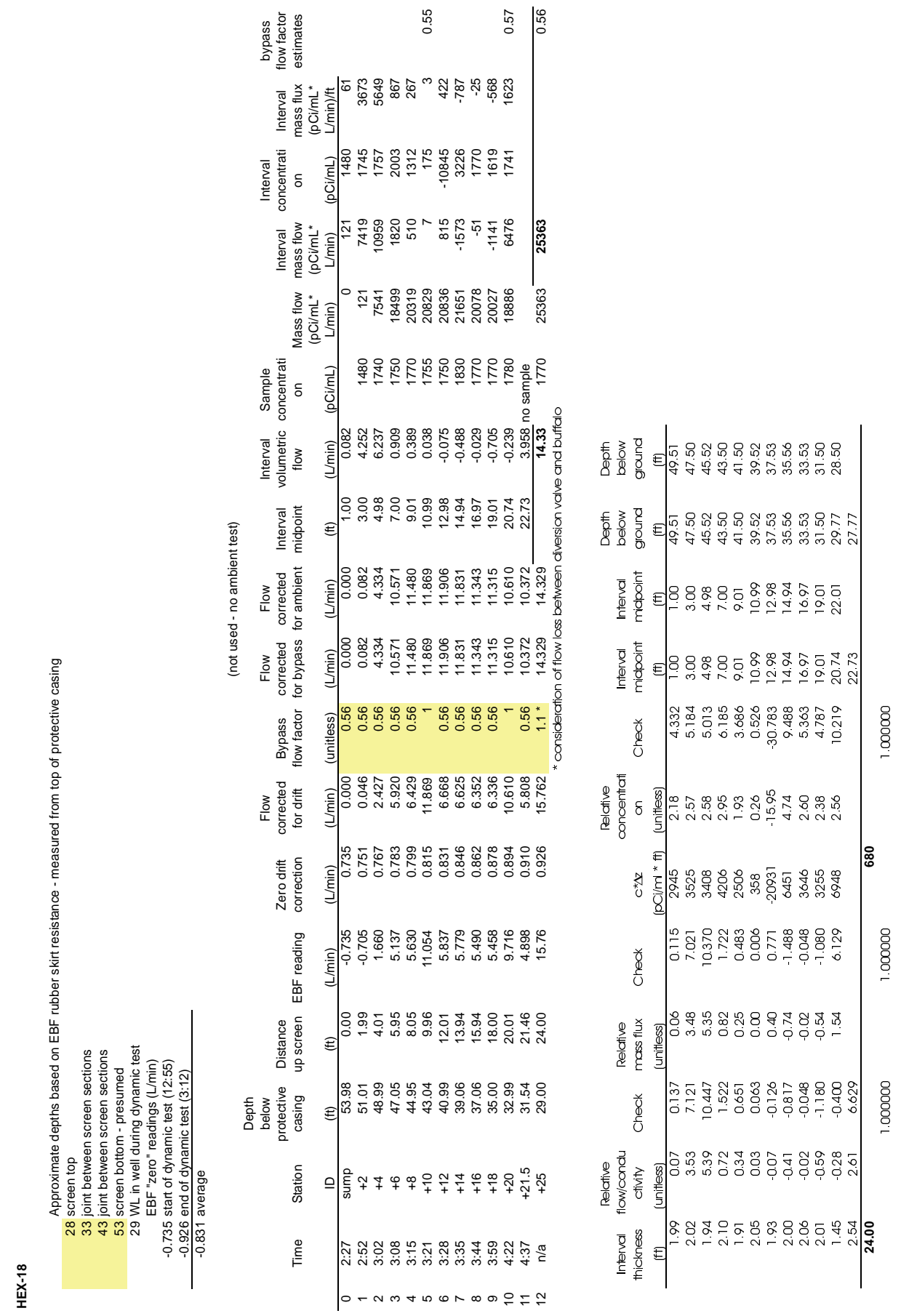

Table 5. Preliminary Data Analysis for HEX-18 
Electromagnetic Borehole Flowmeter Testing

WSRC-TR-2002-00187

at the H-Area Extraction Wells (U)

Revision 0

Savannah River Site

May 2002

Page 37 of 37

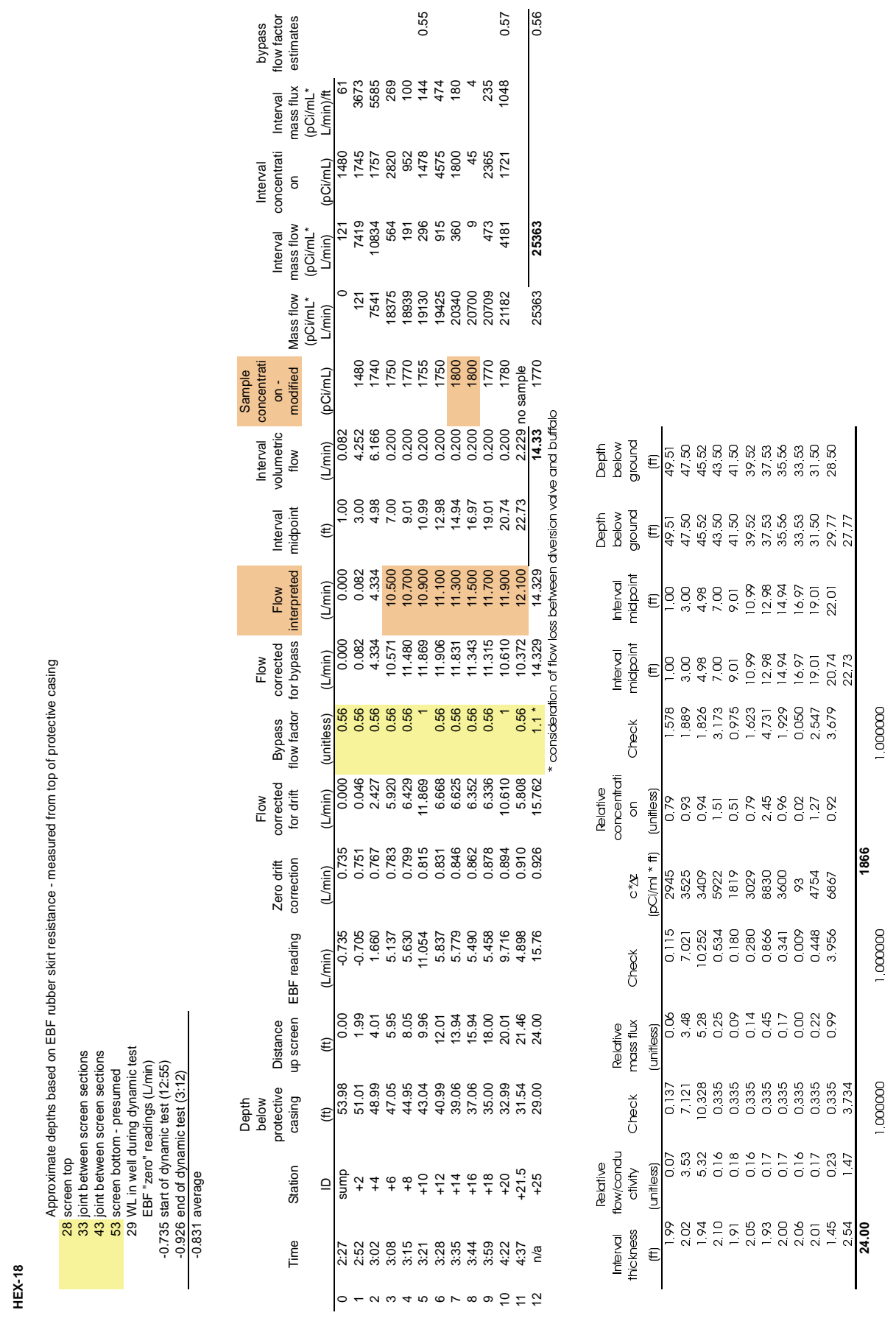

Table 6. Revised Data Analysis for HEX-18 
Electromagnetic Borehole Flowmeter Testing

WSRC-TR-2002-00187

at the H-Area Extraction Wells (U)

Revision 0

Savannah River Site

Month/Year

Page A-1 of A-1

\section{Appendix A}

\section{General Engineering Laboratory (GEL) Mobile Lab Tritium Analysis Results}

\begin{tabular}{|c|c|c|c|c|c|c|c|c|c|c|c|c|}
\hline GEL ID & Client ID1 & Client ID2 & Date Sampled & Analyte & Method & Synonym & MDL & PQL & Units & Result & Uncertainty & Qualifier \\
\hline 55572001 & 01503-HEX-3-1 & & 020402 & Tritium & RADA-002 & TRITIU & 582 & 10942 & $\mathrm{PCL}$ & 654000 & 5180 & \\
\hline 55572002 & 01503-HEX-3-2 & & 020402 & Tritium & RADA-002 & TRITIU & 663 & 12923 & PCL & 806000 & 6130 & \\
\hline 55572003 & 01503-HEX-3-3 & & 020402 & Tritium & RADA-002 & TRITIU & 631 & 11691 & PCL & 687000 & 5530 & \\
\hline 55572004 & 01503-HEX-3-4 & & 020402 & Tritium & RADA-002 & TRITIU & 626 & 11346 & PCL & 652000 & 5360 & \\
\hline 55572005 & 01503-HEX-3-5 & & 020402 & Tritium & RADA-002 & TRITIU & 640 & 11460 & PCL & 648000 & 5410 & \\
\hline 55572006 & 01503-HEX-3-6 & & 020402 & Tritium & RADA-002 & TRITIU & 638 & 11458 & $\mathrm{PCL}$ & 651000 & 5410 & \\
\hline 55572007 & 01503-HEX-3-7 & & 020402 & Tritium & RADA-002 & TRITIU & 638 & 11298 & $\mathrm{PCL}$ & 633000 & 5330 & \\
\hline 55572008 & 01503-HEX-3-10B & & 013102 & Tritium & RADA-002 & TRITIU & 640 & 1330 & $\mathrm{PCL}$ & -265 & 345 & $U$ \\
\hline
\end{tabular}

\begin{tabular}{|c|c|c|c|c|c|c|c|c|c|c|c|c|}
\hline GEL ID & Client ID1 & Client ID2 & Date Sampled & Analyte & Method & Synonym & MDL & PQL & Units & Result & Uncertainty & Qualifier \\
\hline 55684001 & 01503-HEX-4-1 & & 020602 & Tritium & RADA-002 & TRITIU & 639 & 8639 & PCL & 364000 & 4000 & \\
\hline 55684002 & 01503-HEX-4-2 & & 020602 & Tritium & RADA-002 & TRITIU & 687 & 10667 & PCL & 527000 & 4990 & \\
\hline 55684003 & 01503-HEX-4-3 & & 020602 & Tritium & RADA-002 & TRITIU & 669 & 9969 & PCL & 469000 & 4650 & \\
\hline 55684004 & 01503-HEX-4-4 & & 020602 & Tritium & RADA-002 & TRITIU & 666 & 10426 & $\mathrm{PCL}$ & 520000 & 4880 & \\
\hline 55684005 & 01503-HEX-4-5 & & 020602 & Tritium & RADA-002 & TRITIU & 666 & 9806 & $\mathrm{PCL}$ & 456000 & 4570 & \\
\hline 55684006 & 01503-HEX-4-6 & & 020602 & Tritium & RADA-002 & TRITIU & 663 & 9843 & $\mathrm{PCL}$ & 461000 & 4590 & \\
\hline 55684007 & 01503-HEX-4-7 & & 020602 & Tritium & RADA-002 & TRITIU & 638 & 8838 & $\mathrm{PCL}$ & 381000 & 4100 & \\
\hline 55684008 & 01503-HEX-4-8 & & 020602 & Tritium & RADA-002 & TRITIU & 644 & 8824 & $\mathrm{PCL}$ & 377000 & 4090 & \\
\hline 55684009 & 01503-HEX-4-9 & & 020602 & Tritium & RADA-002 & TRITIU & 643 & 9023 & PCL & 396000 & 4190 & \\
\hline 55684010 & 01503-HEX-4-2B & & 013102 & Tritium & RADA-002 & TRITIU & 666 & 1408 & $\mathrm{PCL}$ & -111 & 371 & $\mathrm{U}$ \\
\hline
\end{tabular}

\begin{tabular}{|c|c|c|c|c|c|c|c|c|c|c|c|c|}
\hline GEL ID & Client ID1 & Client ID2 & Date Sampled & Analyte & Method & Synonym & MDL & PQL & Units & Result & Uncertainty & Qualifier \\
\hline 55955001 & 01503-HEX18-1 & & 021102 & Tritium & RADA-002 & TRITIU & 593 & 18233 & PCL & 1780000 & 8820 & \\
\hline 55955002 & 01503-HEX18-2 & & 021102 & Tritium & RADA-002 & TRITIU & 608 & 16928 & PCL & 1480000 & 8160 & \\
\hline 55955003 & 01503-HEX18-3 & & 021102 & Tritium & RADA-002 & TRITIU & 623 & 18523 & PCL & 1740000 & 8950 & \\
\hline 55955004 & 01503-HEX18-4 & & 021102 & Tritium & RADA-002 & TRITIU & 609 & 18369 & PCL & 1750000 & 8880 & \\
\hline 55955005 & 01503-HEX18-4B & & 013102 & Tritium & RADA-002 & TRITIU & 616 & 1278 & PCL & -244 & 331 & $\mathrm{U}$ \\
\hline 55955006 & 01503-HEX18-5 & & 021102 & Tritium & RADA-002 & TRITIU & 625 & 18665 & PCL & 1770000 & 9020 & \\
\hline 55955007 & 01503-HEX18-6 & & 021102 & Tritium & RADA-002 & TRITIU & 630 & 18690 & PCL & 1750000 & 9030 & \\
\hline 55955008 & 01503-HEX18-7 & & 021102 & Tritium & RADA-002 & TRITIU & 622 & 18602 & PCL & 1760000 & 8990 & \\
\hline 55955009 & 01503-HEX18-8 & & 021102 & Tritium & RADA-002 & TRITIU & 616 & 18416 & PCL & 1750000 & 8900 & \\
\hline 55955010 & 01503-HEX18-9 & & 021102 & Tritium & RADA-002 & TRITIU & 618 & 18878 & PCL & 1830000 & 9130 & \\
\hline 55955011 & 01503-HEX18-10 & & 021102 & Tritium & RADA-002 & TRITIU & 597 & 18237 & PCL & 1770000 & 8820 & \\
\hline 55955012 & 01503-HEX18-11 & & 021102 & Tritium & RADA-002 & TRITIU & 618 & 18558 & PCL & 1770000 & 8970 & \\
\hline 55955013 & 01503-HEX18-12 & & 021102 & Tritium & RADA-002 & TRITIU & 625 & 18725 & PCL & 1780000 & 9050 & \\
\hline 55955014 & 01503-HEX18-13 & & 021102 & Tritium & RADA-002 & TRITIU & 619 & 18579 & PCL & 1760000 & 8980 & \\
\hline
\end{tabular}


Electromagnetic Borehole Flowmeter Testing

WSRC-TR-2002-00187

at the H-Area Extraction Wells (U)

Revision 0

Savannah River Site

Month/Year

Page B-1 of B-2

\section{Appendix B \\ Nearby Cone Penetrometer Testing (CPT) Results}

Data for comparison of Cone Penetrometer Tests Upgradient of HEX Wells and EBF Testing at HEX wells; Prepared by Jeff Thibault

\begin{tabular}{|c|c|c|c|c|c|c|c|c|c|c|c|c|}
\hline \multicolumn{2}{|c|}{ Jeff's CPT sample results } & \multicolumn{5}{|c|}{ Location HCPT-03 is approximately $85 \mathrm{ft}$ upgradient of HEX-3 } & \multicolumn{6}{|c|}{ SRS_E 56967.72 SRS_N 71315.0 Elev. 235.2} \\
\hline GEL ID & Client ID1 & Client ID2 & Date Sampled & Analyte & Method & Synonym & MDL & PQL & Units & Result & Uncertainty & Qualifier \\
\hline \multirow{6}{*}{$\begin{array}{l}54993005 \\
54993006 \\
54993007 \\
54993008 \\
54993009 \\
\end{array}$} & \multicolumn{2}{|l|}{ HCPT-03-26 } & 012202 & Tritium & RADA-002 & TRITIU & 627 & \multirow{2}{*}{$\begin{array}{l}14267 \\
26232\end{array}$} & & 1010000 & \multicolumn{2}{|l|}{6820} \\
\hline & \multirow{2}{*}{\multicolumn{2}{|c|}{ HCPT $-03-36$}} & 012202 & Tritium & RADA-002 & TRITIU & 632 & & $\begin{array}{l}\mathrm{PCL} \\
\mathrm{PCL}\end{array}$ & 3560000 & \multicolumn{2}{|l|}{12800} \\
\hline & & & 012202 & Tritium & RADA-002 & TRITIU & 631 & 24431 & PCL & 3070000 & \multicolumn{2}{|l|}{11900} \\
\hline & & 012202 & Tritium & RADA-002 & TRITIU & 554 & 23354 & $\mathrm{PCL}$ & 3200000 & \multicolumn{2}{|l|}{11400} \\
\hline & \multicolumn{2}{|l|}{$\begin{array}{l}\text { НCPI-03-41 } \\
\text { HCPT-03-50 }\end{array}$} & 012202 & Tritium & RADA-002 & TRITIU & 635 & 9435 & PCL & 415000 & \multicolumn{2}{|l|}{4400} \\
\hline & & & & & & & & & & & & \\
\hline & HCPT-03-\#\# & \multicolumn{6}{|c|}{ \#\# is sample depth below surface (ie, midpoint of 2-ft sample screen) } & & & & & \\
\hline & \multicolumn{12}{|c|}{ Yellow samples were collected stratigraphically from the elevation of the HEX-3 well screen } \\
\hline & & & & & & & & & & & & \\
\hline \multicolumn{13}{|c|}{ Greg's EBF sample results } \\
\hline GEL ID & Client ID1 & Client ID2 & Date Sampled & Analyte & Method & Synonym & MDL & PQL & Units & Result & Uncertainty & Qualifier \\
\hline 55572001 & 01503-HEX-3-1 & & 020402 & Tritium & RADA-002 & TRITIU & 582 & 10942 & PCL & 654000 & 5180 & \\
\hline 55572002 & 01503-HEX-3-2 & & 020402 & Tritium & RADA-002 & TRITIU & 663 & 12923 & PCL & 806000 & 6130 & \\
\hline 55572003 & 01503-HEX-3-3 & & 020402 & Tritium & RADA-002 & TRITIU & 631 & 11691 & PCL & 687000 & 5530 & \\
\hline 55572004 & 01503-HEX-3-4 & & 020402 & Tritium & RADA-002 & TRITIU & 626 & 11346 & PCL & 652000 & 5360 & \\
\hline 55572005 & 01503-HEX-3-5 & & 020402 & Tritium & RADA-002 & TRITIU & 640 & 11460 & PCL & 648000 & 5410 & \\
\hline 55572006 & 01503-HEX-3-6 & & 020402 & Tritium & RADA-002 & TRITIU & 638 & 11458 & PCL & 651000 & 5410 & \\
\hline 55572007 & 01503-HEX-3-7 & & 020402 & Tritium & RADA-002 & TRITIU & 638 & 11298 & PCL & 633000 & 5330 & \\
\hline 55572008 & 01503-HEX-3-10B & & 013102 & Tritium & RADA-002 & TRITIU & 640 & 1330 & PCL & -265 & 345 & $\mathrm{U}$ \\
\hline
\end{tabular}

\begin{tabular}{|c|c|c|c|c|c|c|c|c|c|c|c|c|c|}
\hline Location_ID & \begin{tabular}{|c|} 
Sample \\
Depth_ID \\
\end{tabular} & SRS_E & SRS_N & UTM_E & UTM_N & $\begin{array}{l}\text { Ground_ } \\
\text { Elevation }\end{array}$ & $\begin{array}{c}\text { Sample } \\
\text { Top_Depth }\end{array}$ & $\begin{array}{c}\text { Sample } \\
\text { Base_Depth }\end{array}$ & \begin{tabular}{|c|} 
Sample \\
Top_Elevation \\
\end{tabular} & $\begin{array}{c}\text { Sample } \\
\text { Base_Elevation }\end{array}$ & $\mathrm{pH}$ & Tritium_Result & Tritium_Unit \\
\hline HCPT01 & \begin{tabular}{|l|}
30 \\
\end{tabular} & 57816.52 & 71434.88 & & & 244.11 & 29 & 31 & \begin{tabular}{|l|}
215.11 \\
\end{tabular} & \begin{tabular}{|l|}
213.11 \\
\end{tabular} & & $\begin{array}{r}2,270,000 \\
\end{array}$ & $\mathrm{PCL}$ \\
\hline HCPT01 & 35 & 57816.52 & 71434.88 & & & 244.11 & 34 & 36 & 210.11 & 208.11 & & $1,880,000$ & $\mathrm{PCL}$ \\
\hline HCPT01 & 40 & 57816.52 & 71434.88 & & & 244.11 & 39 & 41 & 205.11 & 203.11 & & 729,000 & $\mathrm{PCL}$ \\
\hline HCPT01 & 45 & 57816.52 & 71434.88 & & & 244.11 & 44 & 46 & 200.11 & 198.11 & & 331,000 & $\mathrm{PCL}$ \\
\hline HCPT01 & 52 & 57816.52 & 71434.88 & & & 244.11 & 51 & 53 & 193.11 & 191.11 & & $1,160,000$ & $\mathrm{PCL}$ \\
\hline HCPT01 & 65 & 57816.52 & 71434.88 & & & 244.11 & 64 & 66 & 180.11 & 178.11 & & 173,000 & $\mathrm{PCL}$ \\
\hline HCPT01 & 74 & 57816.52 & 71434.88 & & & 244.11 & 73 & 75 & 171.11 & 169.11 & & 74,700 & $\mathrm{PCL}$ \\
\hline HCPT01 & 90 & 57816.52 & 71434.88 & & & 244.11 & 89 & 91 & 155.11 & 153.11 & & 178,000 & $\mathrm{PCL}$ \\
\hline HCPT01 & 119 & 57816.52 & 71434.88 & & & 244.11 & 118 & 120 & 126.11 & 124.11 & & 70,200 & $\mathrm{PCL}$ \\
\hline
\end{tabular}

highlighted samples correspond approximately to HEX-18 screen zone 
Electromagnetic Borehole Flowmeter Testing

WSRC-TR-2002-00187

at the H-Area Extraction Wells (U)

Revision 0

Savannah River Site

Page B-2 of B-2

\section{Appendix B}

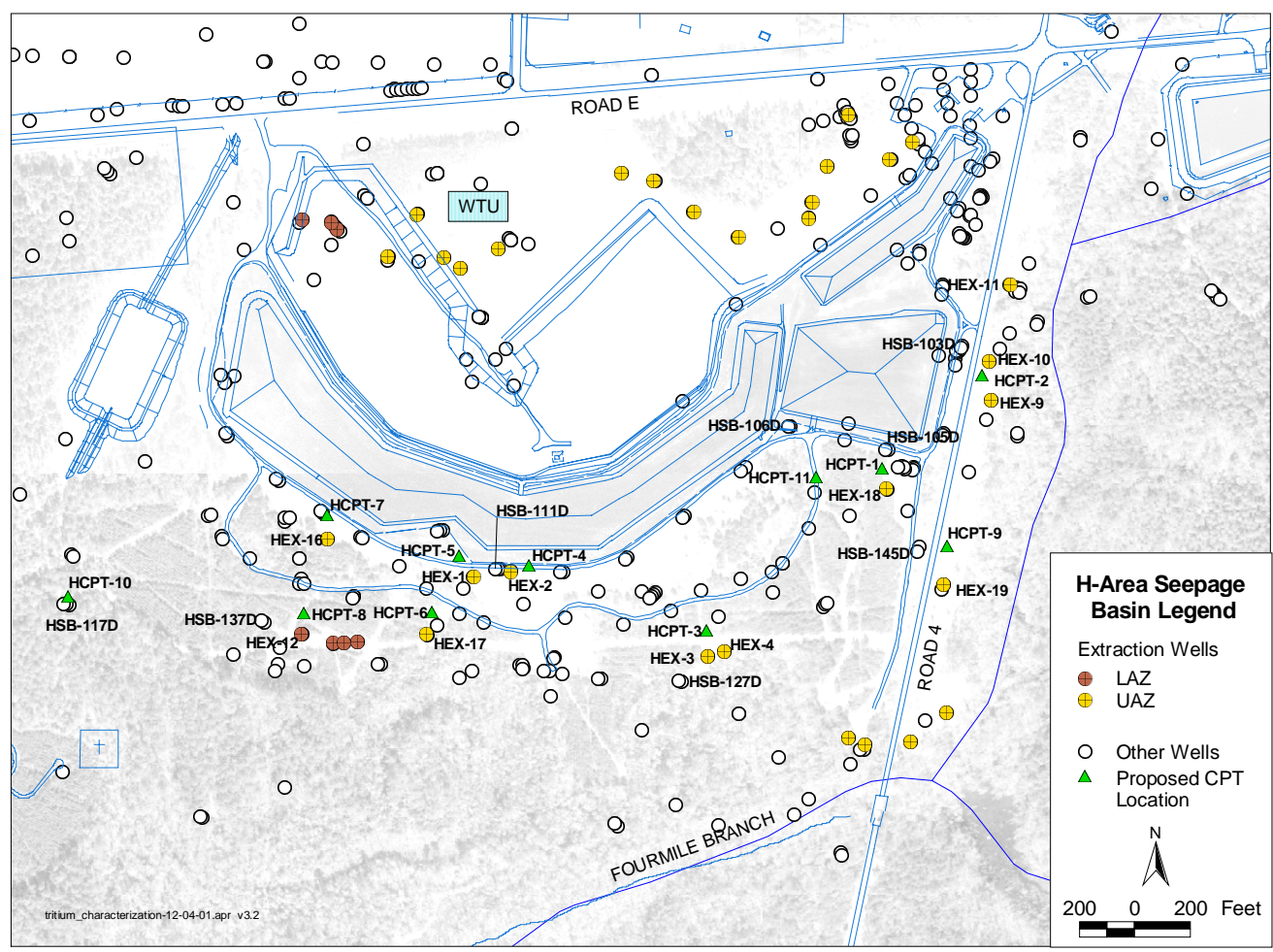

